\title{
Post-depositional fracturing and subsidence of pumice flow deposits: Lascar Volcano, Chile
}

\author{
Patrick L. Whelley • J. Jay • E. S. Calder • \\ M. E. Pritchard • N. J. Cassidy • S. Alcaraz • A. Pavez
}

Received: 11 September 2010 / Accepted: 22 August 2011 / Published online: 27 September 2011

(C) Springer-Verlag 2011

\begin{abstract}
Unconsolidated pyroclastic flow deposits of the 1993 eruption of Lascar Volcano, Chile, have, with time, become increasingly dissected by a network of deeply penetrating fractures. The fracture network comprises orthogonal sets of decimeter-wide linear voids that form a pseudo-polygonal grid visible on the deposit surface. In this work, we combine shallow surface geophysical imaging tools with remote sensing observations and direct field measurements of the deposit to investigate these fractures and their underlying causal mechanisms. Based on ground penetrating radar images, the fractures are observed to have propagated to depths of up to $10 \mathrm{~m}$. In addition, orbiting
\end{abstract}

Editorial responsibility: B. van Wyk de Vries

Electronic supplementary material The online version of this article (doi:10.1007/s00445-011-0545-1) contains supplementary material, which is available to authorized users.

P. L. Whelley $(\bowtie) \cdot$ E. S. Calder

Department of Geology, University at Buffalo,

State University of New York,

411 Cooke Hall,

Buffalo, NY 14260-3050, USA

e-mail: pwhelley@buffalo.edu

J. Jay $\cdot$ M. E. Pritchard

Department of Earth as Atmospheric Sciences, Cornell University, Ithaca, NY, USA

N. J. Cassidy

School of Physical and Geographical Sciences, Keele University, Keele, UK

\section{S. Alcaraz}

Department of Earth Sciences, The Open University,

Milton Keynes MK7 6AA, UK

A. Pavez

Departamento de Geofísica, Universidad de Chile,

Santiago, Chile radar interferometry shows that deposit subsidence of up to $1 \mathrm{~cm} /$ year occurred between 1993 and 1996 with continued subsidence occurring at a slower rate thereafter. In situ measurements show that $1 \mathrm{~m}$ below the surface, the 1993 deposits remain $5^{\circ} \mathrm{C}$ to $15^{\circ} \mathrm{C}$ hotter, 18 years after emplacement, than adjacent deposits. Based on the observed subsidence as well as estimated cooling rates, the fractures are inferred to be the combined result of deaeration, thermal contraction, and sedimentary compaction in the months to years following deposition. Significant environmental factors, including regional earthquakes in 1995 and 2007, accelerated settling at punctuated moments in time. The spatially variable fracture pattern relates to surface slope and lithofacies variations as well as substrate lithology. Similar fractures have been reported in other ignimbrites but are generally exposed only in cross section and are often attributed to formation by external forces. Here we suggest that such interpretations should be invoked with caution, and deformation including post-emplacement subsidence and fracturing of loosely packed ash-rich deposits in the months to years postemplacement is a process inherent in the settling of pyroclastic material.

Keywords Lascar · Ignimbrite · InSAR · Ground penetrating radar $\cdot$ Compaction $\cdot$ Deaeration $\cdot$ Cooling

\section{Introduction}

We document a network of fractures, which are progressively dissecting the 18-20 April 1993 pumice flow deposits at Lascar Volcano, Chile (Fig. 1). The fractures are manifest at the surface as elongate irregular trenches, which cut through unconsolidated ignimbrite. They represent the first stages of post-depositional deformation of 
Fig. 1 a The location of Lascar Volcano in northern Chile. b View of Lascar from an overlooking cliff to the north showing the northwest fan of 1993 deposits. c Individual pyroclastic flow units on breakout fans I and II, mapped on a portion of GEOTEC image 14602-04. Relative stratigraphic positions were deduced by field observations
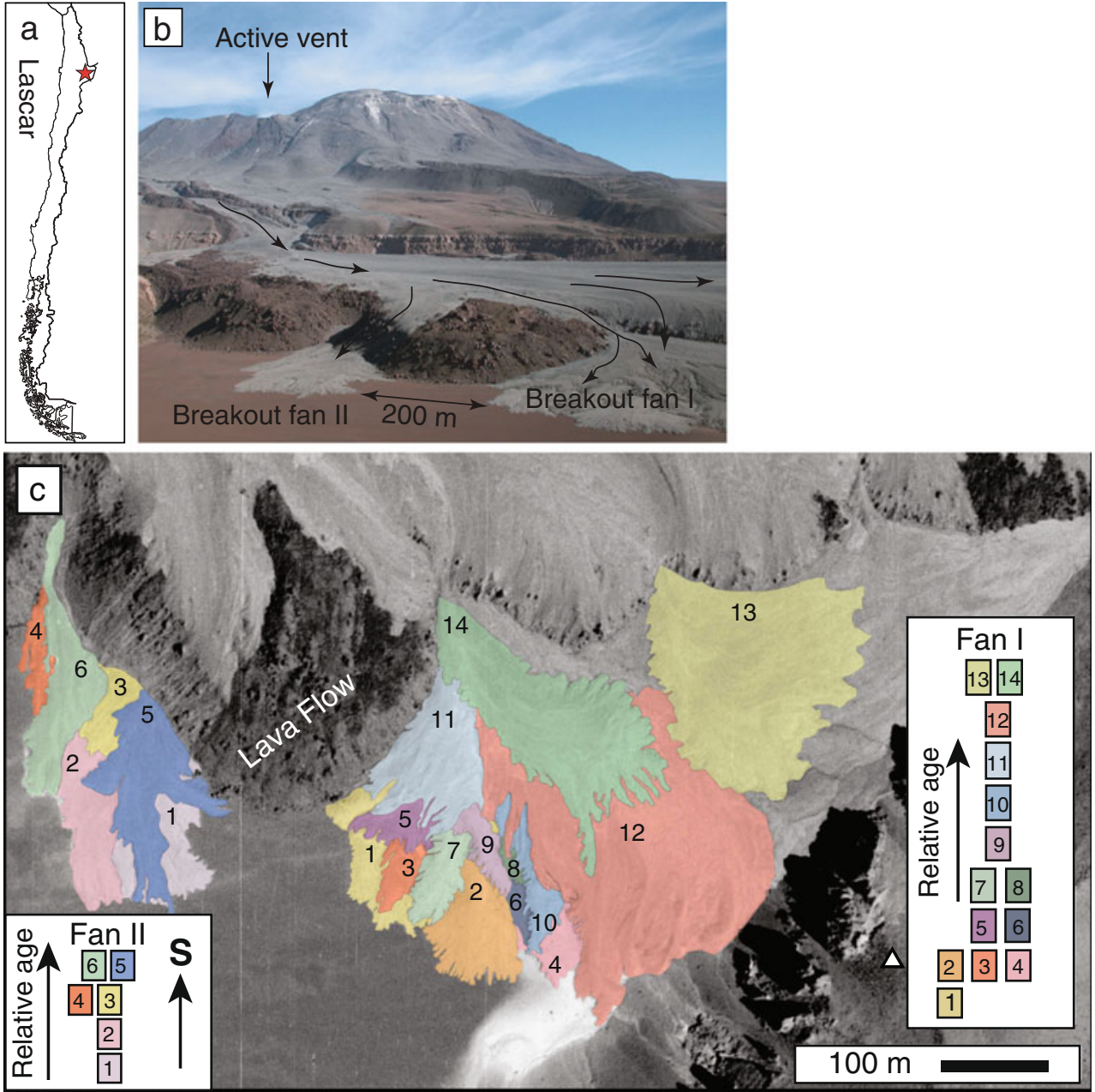

ignimbrite in an arid environment. Their presence at Lascar provides an opportunity to map their distribution, monitor their development, and constrain the timescales over which their formative processes operate. This work furthers the understanding of how pyroclastic materials behave and are modified by, or respond to, environmental factors in the decades after emplacement.

Post-depositional deformation of pyroclastic deposits occurs over a range of spatial and temporal scales (Table 1). Internally driven processes, such as deaeration, cooling, initial compaction, and the onset of welding, are dependent on the eruptive conditions and material properties, including grain size and composition. These processes begin to occur during and immediately after emplacement, but the timescales over which they extend are not well constrained. The deposits studied here are non-welded and largely unconsolidated, so welding, which is extensively covered elsewhere (e.g., Ross and Smith 1961; Wolff and Wright 1981; Sparks et al. 1999), is not considered here. Recent laboratory experiments on fluidized natural samples (e.g., Druitt et al. 2004, 2007) found that deaeration reduced deposit thickness by $50 \%$, in the minutes after emplacement. In natural systems, a continuum must exist between deaeration and the longerterm effects of compaction involving reduction of void space and grain reorientation, but this has never been specifically investigated. Field observations of easily fluidized fresh deposits are common (Rowley et al. 1981; Wilson and Head 1981; Torres et al. 1996; Branney and Kokelaar 2002; P. Cole, personal communication, 1997) and indicate that at the natural scale, deaeration must continue over longer time periods (days to weeks) than can be reproduced in the laboratory (e.g., Druitt et al. 2004, 2007).

External forces drive additional processes which may affect those already mentioned: Seismic ground acceleration can induce fracturing (e.g., Nocita 1988; Brown and Branney 2004), circulating fluids or volatiles can cement or indurate unconsolidated deposits (e.g., Zies 1924; Bacon 2008; Calder et al. 2000), and mass wasting and fluvial or eolian erosion modify the aspect of the deposits. Mass wasting and fluvial erosion can also induce secondary flow phenomena including deposit-derived pyroclastic flows (Torres et al. 1996), debris flows, and hyper-concentrated lahars (e.g., Pierson et al. 1992; Branney and Gilbert 1995; Major et al. 1996). The deposit-derived pyroclastic flows at 
Table 1 Post-depositional processes affecting ignimbrites

\begin{tabular}{|c|c|c|c|c|c|}
\hline Process & & Time scale & Features/effects & Example & Reference \\
\hline \multirow[t]{6}{*}{$\begin{array}{l}\text { Internal } \\
\text { (lithological) }\end{array}$} & Deaeration & Minutes to years & Density increase & $\begin{array}{l}\text { Mt. St. Helens, } \\
\text { laboratory experiments }\end{array}$ & $\begin{array}{l}\text { Wilson and Head 1981; } \\
\text { Rowley et al. 1981; Druitt et al. } \\
\text { 2004, } 2007\end{array}$ \\
\hline & Welding & Minutes to days & $\begin{array}{l}\text { Eutaxitic fabric, } \\
\text { fiamme, joints }\end{array}$ & $\begin{array}{l}\text { Bishop Tuff, Murga } \\
\text { Caldera Ignimbrites }\end{array}$ & $\begin{array}{l}\text { Ross and Smith 1961; } \\
\text { Sparks et al. } 1999\end{array}$ \\
\hline & Rheomorphism & $\begin{array}{l}\text { Minutes to hours } \\
\text { to days }\end{array}$ & $\begin{array}{l}\text { Flow lineations, deposit } \\
\text { thickness variations, } \\
\text { eutaxitic fabric }\end{array}$ & $\begin{array}{l}\text { Borrowdale Volcanic } \\
\text { Group, TL Ignimbrite }\end{array}$ & $\begin{array}{l}\text { Schmincke and Swanson } \\
\text { 1967; Sumner and } \\
\text { Branney 2002; Branney } \\
\text { et al. } 2004\end{array}$ \\
\hline & Compaction & Weeks to decades & $\begin{array}{l}\text { Fracture network, } \\
\text { subsidence }\end{array}$ & $\begin{array}{l}\text { Grants Ridge Tuff, } \\
\text { Lascar } \\
\text { pumice flow deposit }\end{array}$ & $\begin{array}{l}\text { Keating and Valentine } \\
\text { 1998; this work }\end{array}$ \\
\hline & Cooling & Years & Joints & Bishop Tuff & Sheridan 1970 \\
\hline & Induration $^{\mathrm{a}}$ & $\begin{array}{l}\text { Decades to millions } \\
\text { of years }\end{array}$ & $\begin{array}{l}\text { Hardening, fumarolic } \\
\text { incrustations, mounds } \\
\text { and ridges }\end{array}$ & $\begin{array}{l}\text { Valley of 10,000 Smokes; } \\
\text { Bishop Tuff; Akdag- } \\
\text { Zelve Ignimbrite; } \\
\text { Mazama-Crater } \\
\text { Lake }\end{array}$ & $\begin{array}{l}\text { Griggs 1922; Sheridan } \\
\text { 1970; Schumacher and } \\
\text { Mues-Schumacher 1997; } \\
\text { Bacon } 2008\end{array}$ \\
\hline \multirow[t]{6}{*}{$\begin{array}{l}\text { External } \\
\text { (environmental) }\end{array}$} & Aeolian erosion & $\begin{array}{l}\text { Days to millions } \\
\text { of years }\end{array}$ & Yardangs, pits & Tara Ignimbrite & Bailey et al. 2007 \\
\hline & Fluvial erosion & Days to decades & Gullies, channels & Atana Ignimbrite & Bailey et al. 2007 \\
\hline & Mass wasting & Days to millennia & $\begin{array}{l}\text { Fractures, debris } \\
\text { flows, lahars }\end{array}$ & Pinatubo & Pierson et al. 1992 \\
\hline & Remobilization & Days to years & $\begin{array}{l}\text { Secondary pyroclastic } \\
\text { flow deposits }\end{array}$ & Pinatubo & Torres et al. 1996 \\
\hline & $\begin{array}{l}\text { Seismic } \\
\text { perturbation }\end{array}$ & Weeks to decades & $\begin{array}{l}\text { Pyroclast } \\
\text { reorganization }\end{array}$ & $\begin{array}{l}\text { Gramts Ridge Tuff, } \\
\text { Poris Ignimbrite, } \\
\text { Lascar pumice } \\
\text { flow deposit }\end{array}$ & $\begin{array}{l}\text { Keating and Valentine } \\
\text { 1998; Brown and Branney } \\
\text { 2004; this work }\end{array}$ \\
\hline & $\begin{array}{l}\text { Tectonic } \\
\text { deformation }\end{array}$ & $\begin{array}{l}\text { Millions of } \\
\text { years }\end{array}$ & $\begin{array}{l}\text { Lineaments, } \\
\text { alluvial fans }\end{array}$ & La Pacana Ignimbrites & Riquelme et al. 2003 \\
\hline
\end{tabular}

${ }^{\text {a }}$ Partially controlled by external forcing

Pinatubo that were generated up to 4 years after original deposit emplacement (Torres et al. 1996) are poignant examples where post-emplacement processes (mass wasting, fluvial erosion, and resultant pore pressure increases) affecting an ignimbrite have hazardous consequences.

The deposits of the 1993 Lascar pyroclastic flows are well studied. Readers are directed to Guarinos and Guarinos (1993) and Gardeweg and Medina (1994) for detailed accounts of the chronology of the 1993 eruption. A map of the distribution of the 1993 pyroclastic flow deposits is given in Fig. 10 in Calder et al. (2000) and interpretation of emplacement mechanisms are provided in Sparks et al. (1997) and Cassidy et al. (2009). None of these papers, however, documents the fractures or deal with post-emplacement processes.

Here, we characterize the external and internal extent of the Lascar 1993 deposit fracture network and relate these to other coeval deposit changes to constrain the deformation processes' origin. Multiple tools are used: ground penetrating radar (GPR), radar interferometry (InSAR), aerial photogrammetry, field observations, and measurements, which together provide a unique multi-parametric perspective of the deposit. GPR is a useful tool to determine internal architecture of pyroclastic deposits (Cassidy et al. 2003; Gómez-Ortiz et al. 2006; Cassidy et al. 2009). At Lascar, GPR imaging has already provided information on buried morphology of the deposits (Cassidy et al. 2009). Remote sensing tools that provide time series observations on surface elevation (e.g., SAR, InSAR, and LiDAR) are more commonly used in volcanology to detect volcanoscale internally induced ground deformation. However, these techniques also have huge potential in the field of volcanic feature and deposit mapping, which is largely undeveloped (e.g., Csatho et al. 2008; Saepuloh and Koike 2010), and in detecting deformation associated with postdepositional processes (e.g., Wadge et al. 2006; Lee et al. 2008; Poland 2010). Through the use of these combined approaches, this work provides a more complete understanding than can be gained from a single tool and further promotes the wider application of geophysical and remote sensing tools in the study of volcanic deposits. 


\section{Fracture network}

Deposit-wide distribution

The fractures described are on the northwestern fan of the 1993 deposits that extends $9 \mathrm{~km}$ from the summit (Fig. 1), although minor fractures have also been observed on Lascar's southern flanks. Fractures are found within poorly sorted, unconsolidated, pumice-rich ignimbrite with a fine ash matrix, variable lithic content, and a maximum thickness of $\sim 30 \mathrm{~m}$ (Calder et al. 2000). At the northern limits of the deposit, the 1993 flows overtopped the underlying blocky andesite lava flow producing a fan (referred herein as breakout fan I). The fractures on the surface of this fan are prominent, and their study is facilitated by an overlooking cliff-top vantage point (Fig. 2a). Apart from the ash-rich surface near the breakout fan apex, all deposit units have a variable pumice- or scoria-rich surface with matrix-free lobe margins and are
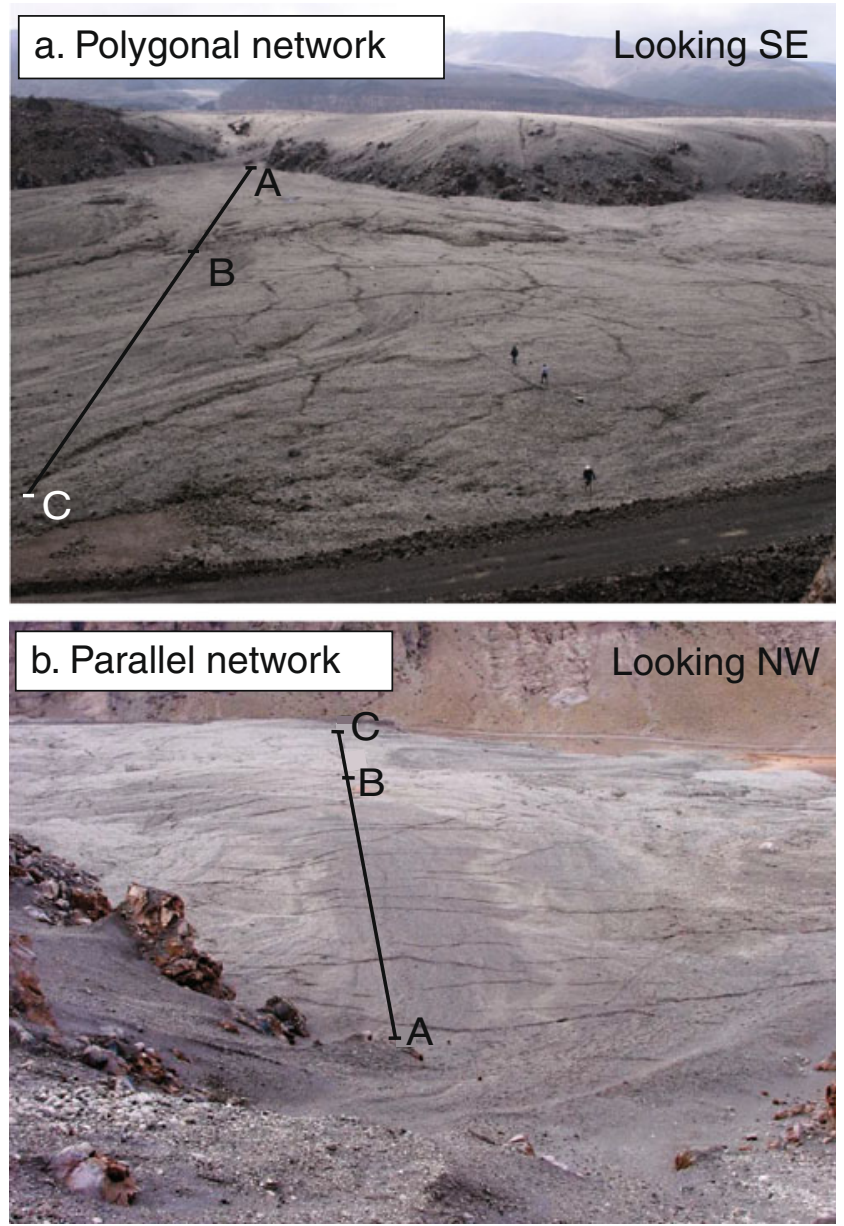

Fig. 2 Fractures on breakout fan I. a A polygonal fracture network is typical of the distal fractures while $\mathbf{b}$ strike parallel fractures are typical near the apex of the fan where the deposit is the thickest. GPR was undertaken along profile $\mathrm{A}-\mathrm{C}$ internally matrix supported. Juvenile clasts are dominantly pale gray (silicic andesite pumice 60.4-61.4 wt.\% $\mathrm{SiO}_{2}$ ), dark gray (mafic andesite scoria 57.6-58.7 wt.\% $\mathrm{SiO}_{2}$ ), or compositionally banded (Matthews 1999). Pumice porosity is typically $40-60 \%$ (Calder et al. 2000).

The fractures appear as linear to sub-linear V-shaped troughs atop the deposit and are a partially in-filled surface manifestation of open fractures at depth (see "Fractures in section"). They are commonly 30 to $60 \mathrm{~cm}$ wide with irregular margins and can extend hundreds of meters in length (Fig. 3). The most pronounced troughs intersect at angles greater than $60^{\circ}$ and frequently reach $120^{\circ}$ while smaller troughs intersect at angles as low as $10^{\circ}$.

Breakout fan I fracture network

The flows that deposited breakout fan I within La Quebrada de Tumbres (Fig. 1b) traveled over the rough surface of the Tumbres-Talabre blocky andesite lava flow (7.1 $\pm 1.25 \mathrm{ka}$; Gardeweg and Sparks 1998) and overspilled onto the underlying Tumbres scoria plain. On the gentle slope of the scoria plain, breakout fan I aggraded as a series of at least nine principal overlapping lobate units (Fig. 1c). Individual pumice-rich units are exposed as wide $250-\mathrm{m}$ fans with tapering margins, lobes 20-50 m wide with digitate but high relief margins, and narrow finger lobes up to $100 \mathrm{~m}$ long and $20 \mathrm{~m}$ wide with well-defined, $0.2-1.2-$ m-high levees and snouts. The principal units can be distinguished easily by morphological boundaries as well as clear grain-size breaks, with accumulations of coarser pumice clasts defining the margins.

The major fractures on this fan are visible in aerial photographs (1:50,000 scale; obtained by the Chilean Air Force Aerophotogrammetric Service in 1998) and have been mapped from these directly (Fig. 4). Geo-referenced photographs taken from the adjacent cliff were used to map less prominent fractures not discernable in aerial photographs. In addition, three transects across breakout fan I collecting fracture positions were undertaken using a pair of Leica SR20 global positioning satellite (GPS) receivers (Figs. 2 and 4). Remotely mapped fracture locations were cross-referenced with in situ fracture observations. The spatial distribution of the fracture network (Fig. 4) mapped by these combined techniques is accurate to $\pm 2 \mathrm{~m}$.

Fractures on breakout fan I preferentially affect gently slopping smooth swathes of 6-25-m-thick deposits. Stratigraphically younger units are affected to a higher degree by fracturing than exposed lower units. The fracture pattern roughly follows contours and is more densely spaced on the upper fan where the deposit surface slope reaches $3.5^{\circ}$ (Figs. 2b and 4). On the lower fan, the slope is only $\sim 2.2^{\circ}$ and the fractures form a pseudo-polygonal pattern with intercept angles between $60^{\circ}$ and $90^{\circ}$ (Figs. 2a and 4). 
Fig. 3 Photographs illustrating the varied morphology and features of the fractures. a Arrows point to dark surface discoloration, inferred to be vapor-phase mineralization, of many clasts adjacent to the fracture. b A fracture near the apex of breakout fan I that is four times as wide at the surface $\left(W_{\mathrm{S}}\right)$ than in the subsurface $\left(W_{\mathrm{D}}\right)$. c A fracture transecting one flow lobe to another. $\mathbf{d}$ Arrows point to bright discoloration (also inferred to be vaporphase mineralization) which is less common than the dark discoloration. e An intersection of multiple fractures
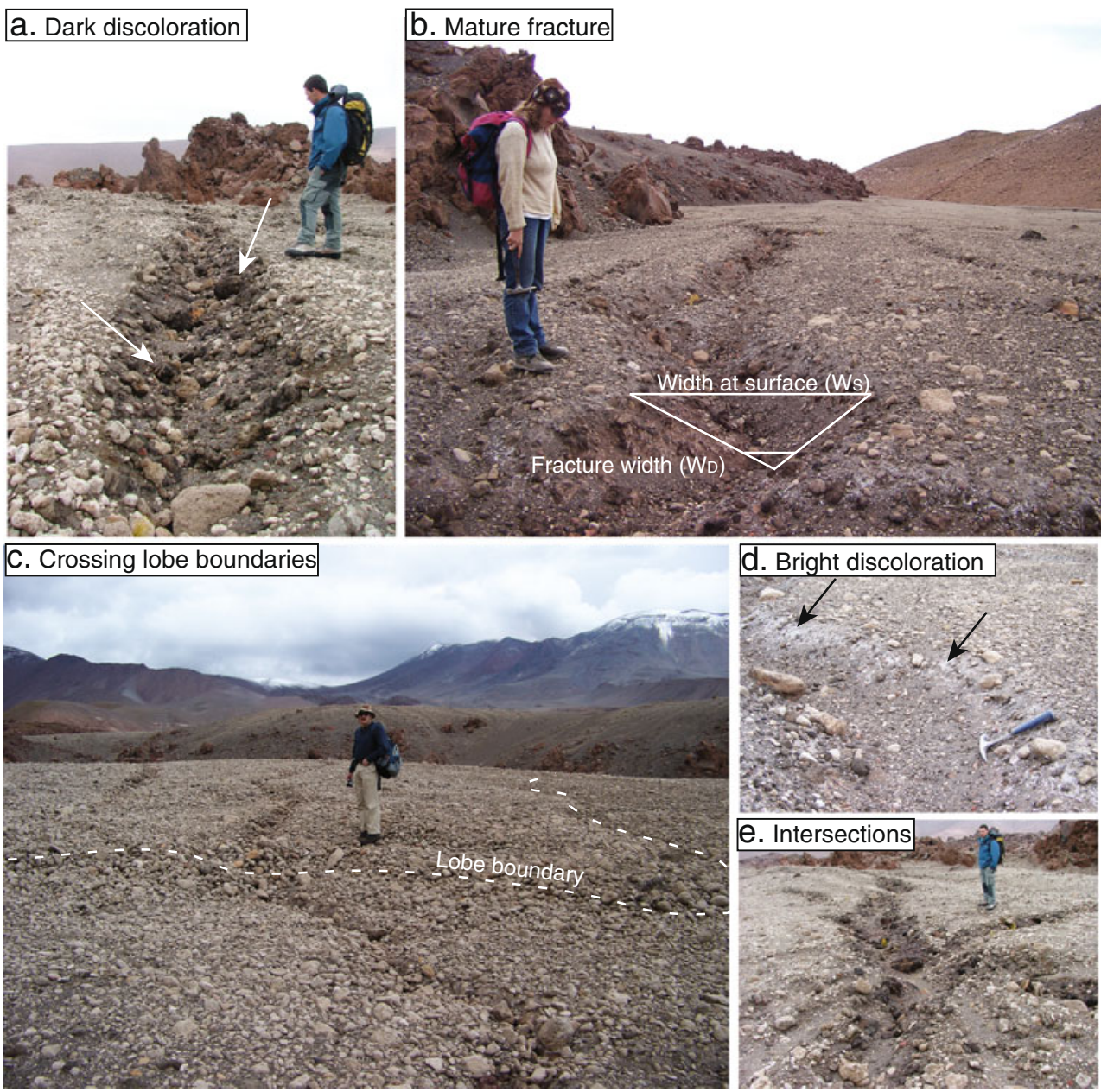

Fractures in section

Excavation of 1-2-m-deep pits in the deposit enabled detailed cross-sectional observations of three fractures. Fractures at depth were roughly bed-perpendicular, nearly vertical (Fig. 5), and contained loosely in-filled pumice supported ignimbrite within the upper $\sim 30 \mathrm{~cm}$ of the fracture opening. However, below $\sim 30 \mathrm{~cm}$, the fractures open to voids $5-10 \mathrm{~cm}$ wide. Many fractures were lined with a thin white or black veneer encrustation from vapor-phase mineralization (mineralogy undetermined). This was consistent with observations of residual degassing emanating from some fractures, evident on occasions when ambient air temperatures were low. Fracture walls were also lined with ash, the cohesion of which was likely aided by the same condensing vapors.

Fracture network development over time

Gardeweg and Sparks (1998) presented aerial photographs (scale 1:30,000) taken on the 26 April 1993, just 6 days after the eruption, and no fractures were observable.
Photographs taken during an over-flight in April 1994, however, show incipient fractures on breakout fans I and II (Fig. 1b). Initial fracturing, therefore, occurred sometime between 26 April 1993 and April 1994. Continued development of the fracture network within breakout fan I is evident from two photographs taken by the authors from the adjacent cliff in 1995 and 2009 (Fig. 6).

\section{Ground penetrating radar imaging of the fractures}

\section{Methods}

GPR data were collected using a Sensors \& Software PE1000 GPR system with 225 and $450 \mathrm{MHz}$ antennae in co-planar, common-offset reflection mode and with a broadside data collection configuration (see Cassidy et al. 2009 for a full description; Fig. 7). A long profile (A-C) was collected running roughly flow parallel and transecting breakout fan I (Fig. 8a). The profile line crossed over 44 observable ash- and pumice-filled fractures whose surface expression ranged in width between 10 and $160 \mathrm{~cm}$ (Fig. 8). Depth evaluations were based on a uniform, 
Fig. 4 a Fractures (bold lines) were mapped using georeferenced photographs taken from an overlooking cliff to the north. Shaded areas are areas obscured in the photographs, where fractures could not be mapped. b To determine how fracture orientation varied spatially, fracture orientations were measured in a sequence of polygons with increasing distance (in $50 \mathrm{~m}$ intervals) from the upper scarp/fan headwall. c Rose diagrams of fracture orientations for all fractures and fractures within each distance polygon. Fractures near the scarp are aligned predominantly parallel to strike, but with distance from the scarp fracture orientation becomes less uniform. d Context map for transects $A-C(390 \mathrm{~m}), D-E$ $(230 \mathrm{~m})$, and $F-G(190 \mathrm{~m})$; flow unit outlines from Fig. 1c
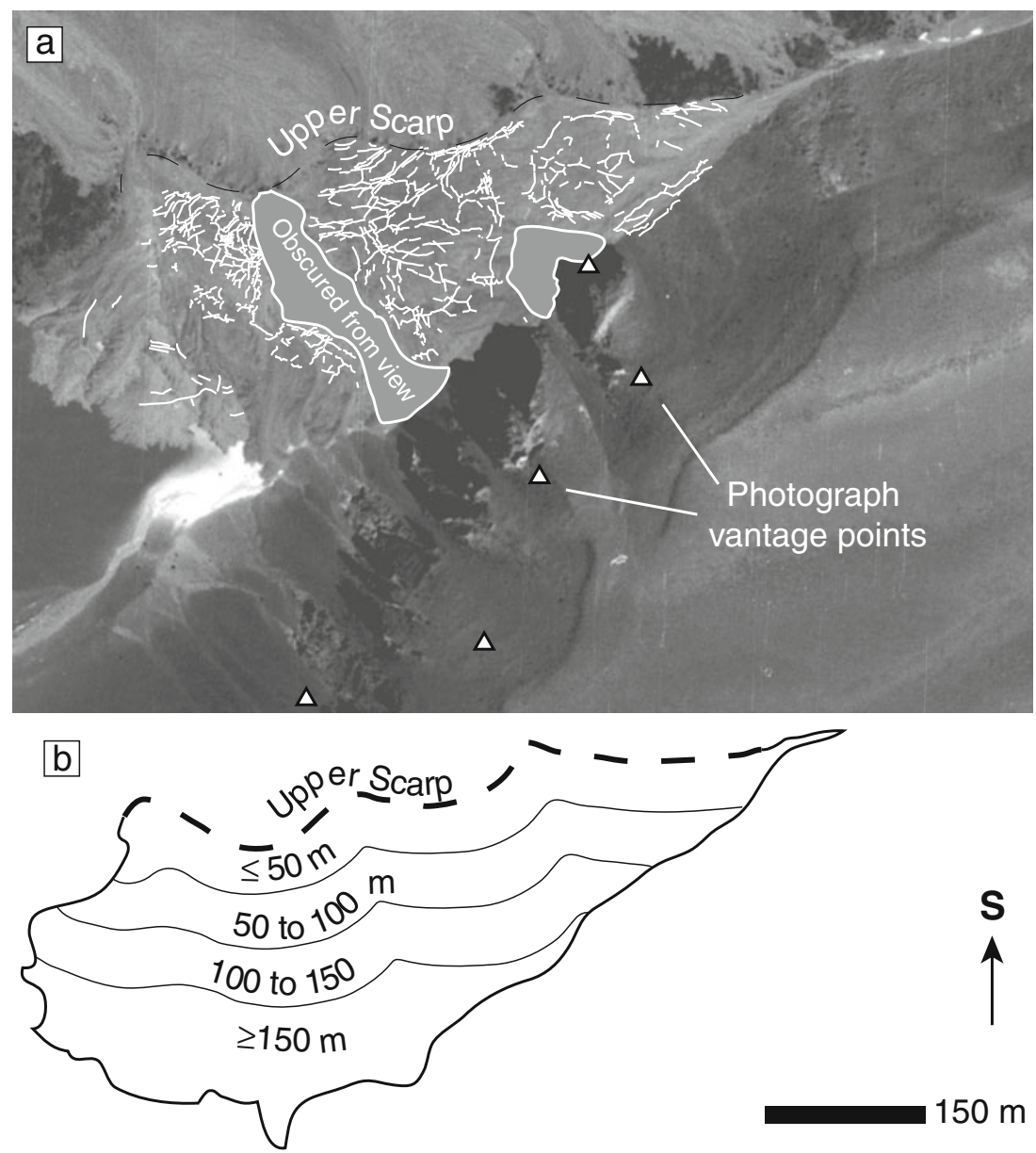

C
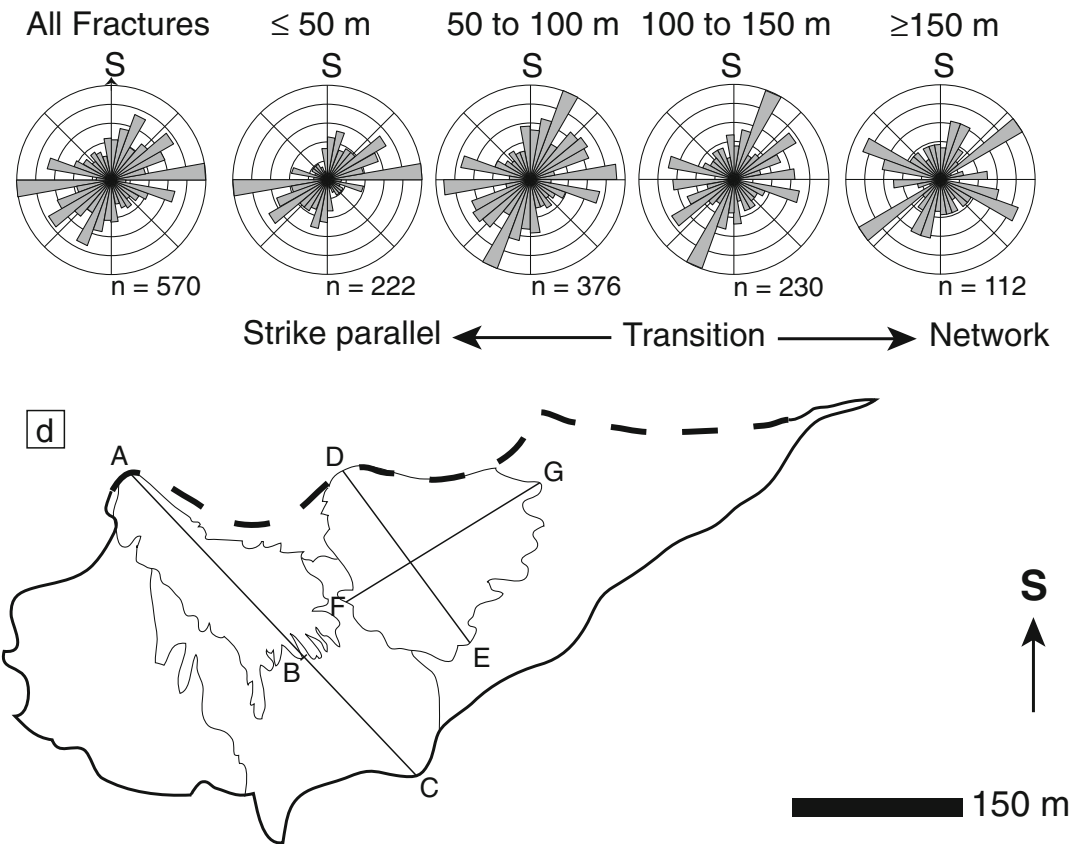

constant velocity of $0.14 \mathrm{~m} / \mathrm{ns}$ obtained from both CMP (common mid-point) and hyperbolic diffraction analysis. This equates to a relative permittivity of approximately $\varepsilon_{\mathrm{r}}=4.5$, indicating the presence of dry deposits at depth. For comparison, the mean velocities reported by Russell and Stasiuk (1997) for comparable pyroclastic flow deposits 
Fig. 5 a A photograph and b sketch of an excavated fracture that exposes the void at depth which continues into the deposit interior. Notice that here the surface expression of the fracture is at least twice the width of the void at depth
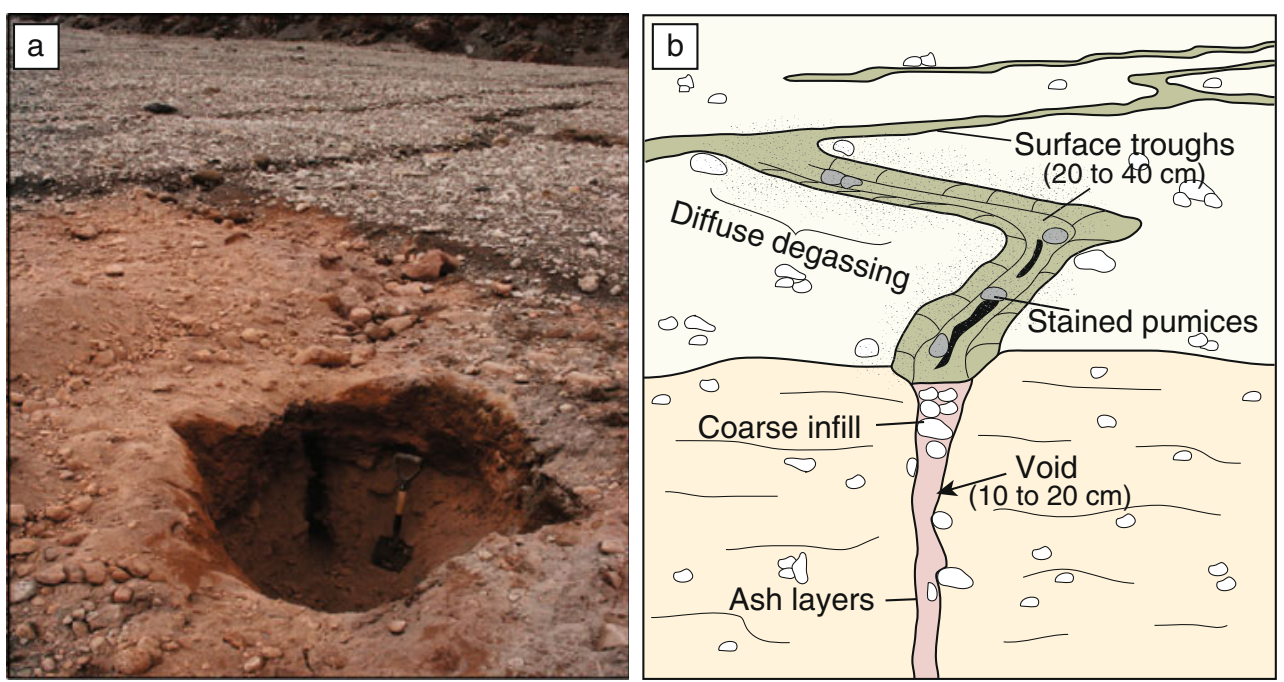
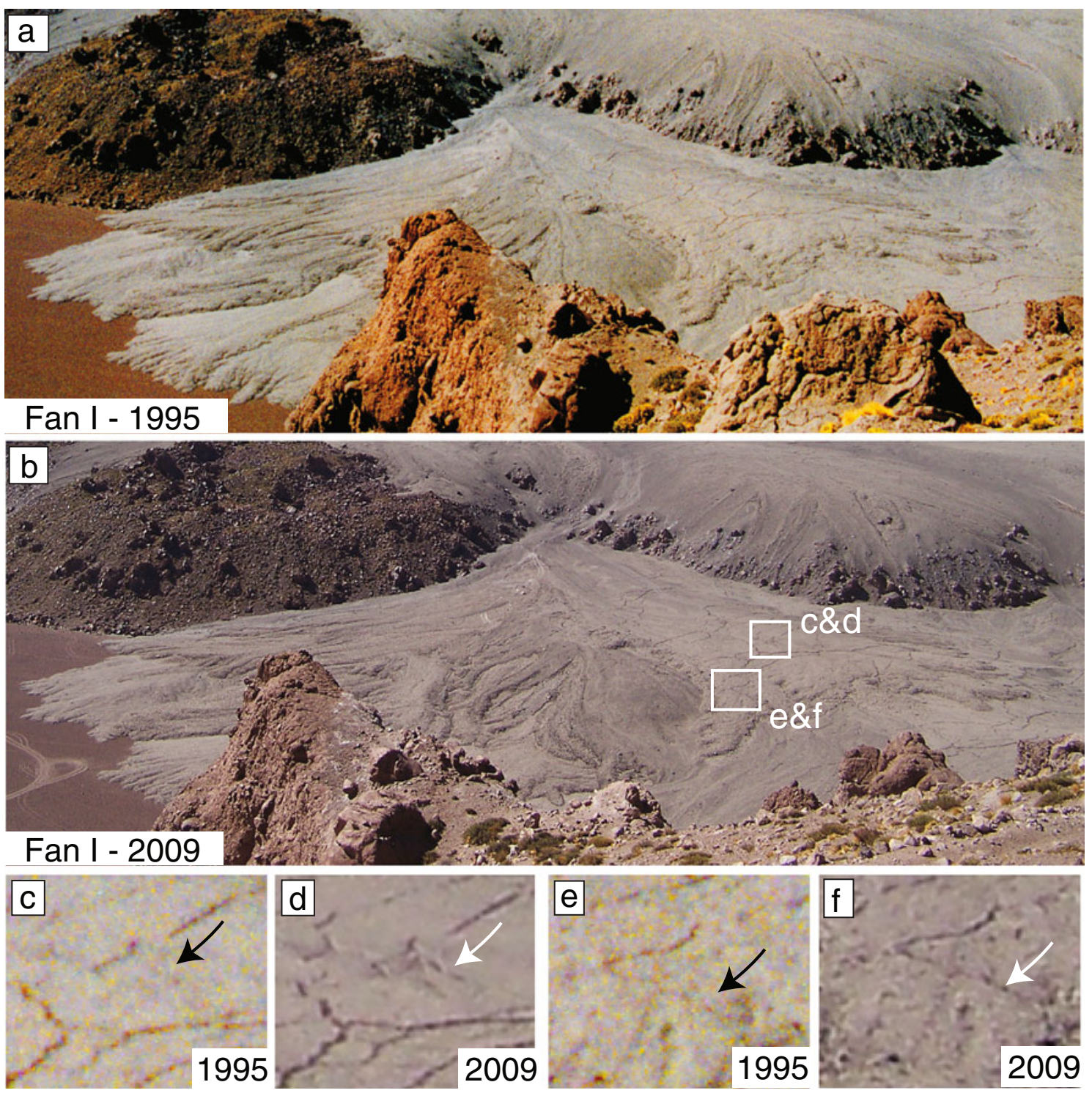

Fig. 6 Photographs of breakout fan I taken from an over looking cliff in a 1995 and b 2009. Most of the fan remained unchanged; however, there are some new fractures ( $\mathbf{c}$ and $\mathbf{d}$ ) and some fractures became more prominent (e and $\mathbf{f}$ ) and we believe have widened 


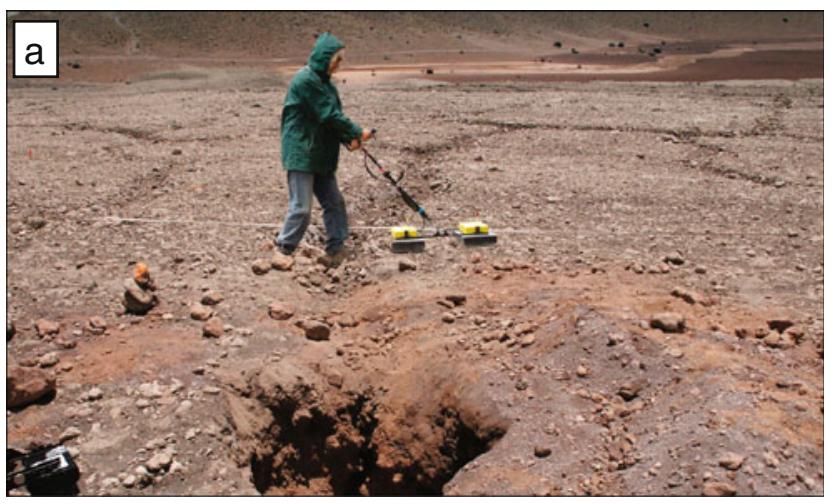

b

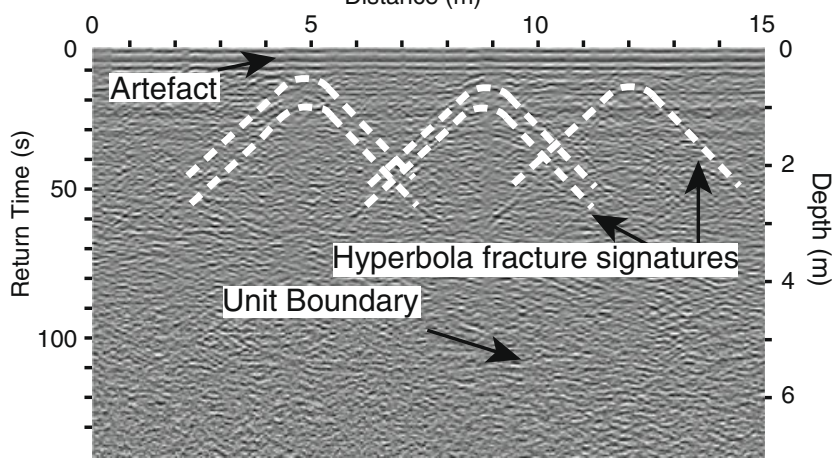

Fig. 7 a GPR survey being undertaken along profile A-C (Fig. 2) on breakout fan I. GPR is based on the measurement of the subsurface response to high-frequency electromagnetic waves transmitted by an antenna placed on the ground surface. The pulses are reflected, diffracted, or scattered at interfaces where the relative permittivity, the conductivity, and/or the relative magnetic permeability change. b GPR results where fractures are observable in the subsurface. Boundaries were determined using higher-resolution data and in a larger format than that represented in the figure; for a thorough description, see Cassidy et al. (2009)

were in the range $0.07-0.12 \mathrm{~m} / \mathrm{ns}$. Due to the high-quality data collected, only simple processing procedures were required in order to obtain interpretable GPR sections (Cassidy et al. 2009). Data were processed in the proprietary GPR data processing package ReflexW ${ }^{\mathrm{TM}}$, with the following steps applied (refer to Cassidy et al. 2009 for further details): de-wow, adjusted to time zero, band-pass filtered, topographically corrected, and converted to a standard grayscale image for interpretation (with gains applied).

\section{Flow parallel section (profiles A-C)}

Within the GPR section, the irregular fracture walls are evident as a narrow band of near-vertical coherent, strong hyperbolic-shaped features (referred to as diffraction hyperbolae) that "stack" on top of each other (Fig. 8c-e) and intersect the deposit's unit boundary interface reflections at depth (for the deepest fractures). Shallow fractures tend to show strong hyperbolic responses in the near surface but
Fig. 8 a, b Full topographic profile obtained by GPS for the A-C profile on breakout fan I (see Fig. 4 for context). All fracture locations visible at surface are marked by red triangles; yellow bars represent fractures observed in the subsurface with GPR. Dashed red lines are deposit interfaces inferred from GPR observations. c An example of a shallow open fracture with strong coherent hyperbolic diffractions only visible in the near surface (indicated by arrow). d An example of a deep open fracture with strong coherent vertical extensive hyperbolic diffractions that intersect inferred deposit interfaces and persist at depth. e A schematic diagram of the open fracture shown in d. Individual hyperbolic diffractions are generated at the decimeterscale irregular interfaces between the low-permittivity void-space and relatively high-permittivity ash/pumice mixture. The arrow points to a reflection horizon within the deposit interpreted as a deposit interface. f Frequency distribution of fracture width at the surface along profile A-C. $g$ Scatter plot of fracture widths verses local slope (represented by average slope of the $50-\mathrm{m}$ segment adjacent to each fracture)

with no extension of the features past the first unit boundary interface. Representative examples are shown in Figs. 7 and 8 along with a schematic diagram of how the features are generated from the irregular morphology of the internal fracture walls (Fig. 8e). The high degree of contrast between the low-permittivity air-filled fractures $\left(\varepsilon_{\mathrm{r}}=1\right)$ and the ignimbrite $\left(\varepsilon_{\mathrm{r}} \sim 4.5\right)$ results in strong, well-defined diffractions being generated that are indicative of open, decimeter-scale void spaces. The presence of areas of increased signal scattering immediately above the shallowest hyperbolae reflects the near surface in-fill of the fractures with sub-decimeter-sized pumice clasts and ashy matrix (Fig. 8). The GPR section interpretation (shown in Fig. 8 for the entire $400-\mathrm{m}$-long profile) shows the interpreted range of fracture depths with the most extensive reaching to depths of $\sim 10 \mathrm{~m}$ below the surface. The GPR section also reveals that the fractures are approximately vertical and often cut through multiple unit boundaries. Some of the GPR-interpreted fractures evident at depth lack an observable surface expression. As troughs are highly distinctive, it is unlikely that these fractures had previously been manifest at the surface and were obscured. It is likely that these "blind" fractures have yet to propagate to the surface of the deposit. A number of observable fractures at the surface do not have an accompanying response in the GPR section. It is probable that these relate to shallow, near surface fractures that are almost completely in-filled with ash and pumice material at a scale that is below the imaging resolution of the GPR system (i.e., centimeter scale). On the whole, the consistency of feature location between surface and GPR observations attests to the reliability of the GPR data for fracture mapping. Interestingly, the hyperbolic responses are easier to see in the $225-\mathrm{MHz}$ sections rather than the $450-\mathrm{MHz}$ data. Although counterintuitive (higher frequencies should produce higher-resolution data), this is a common feature of GPR data in environments where the higher-frequency GPR signal is detrimentally scattered by centimeter-plus sized objects (Cassidy et al. 2009). 


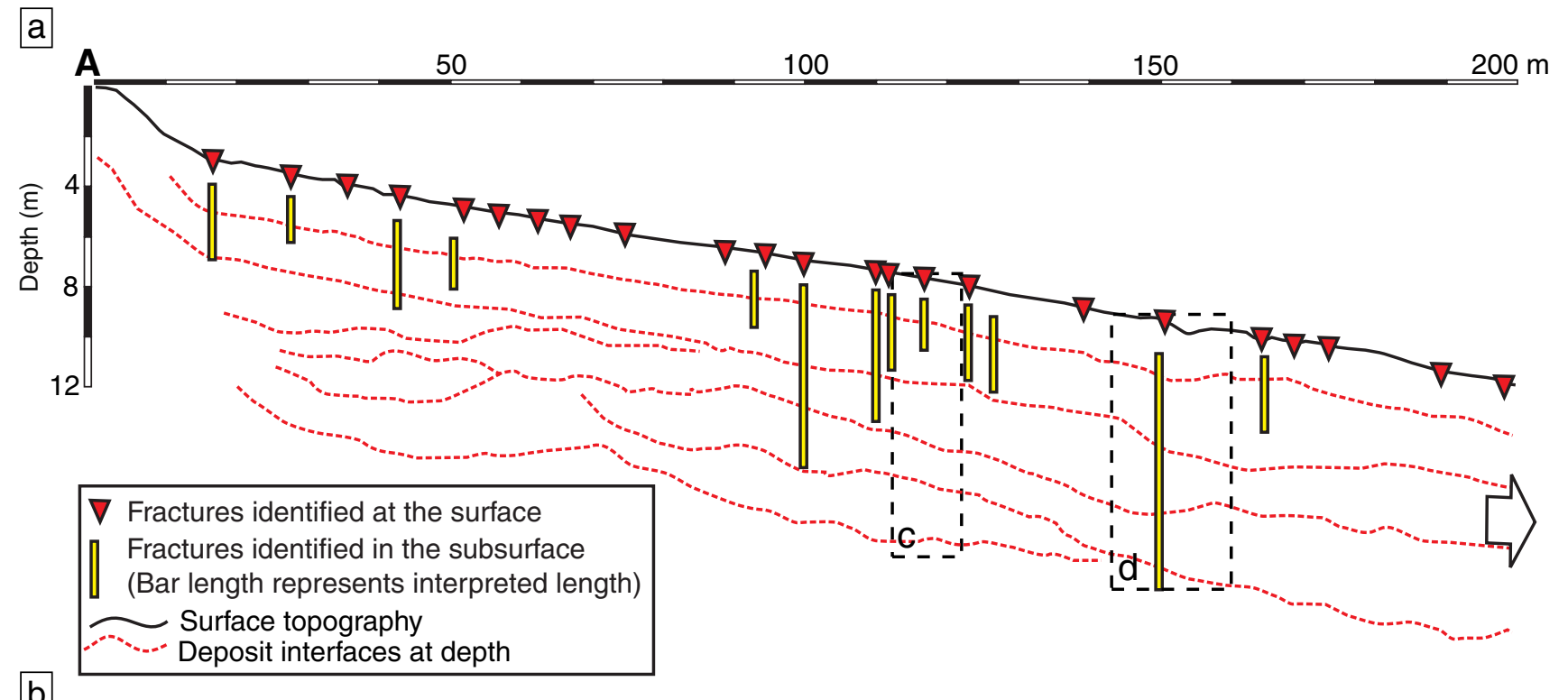

b
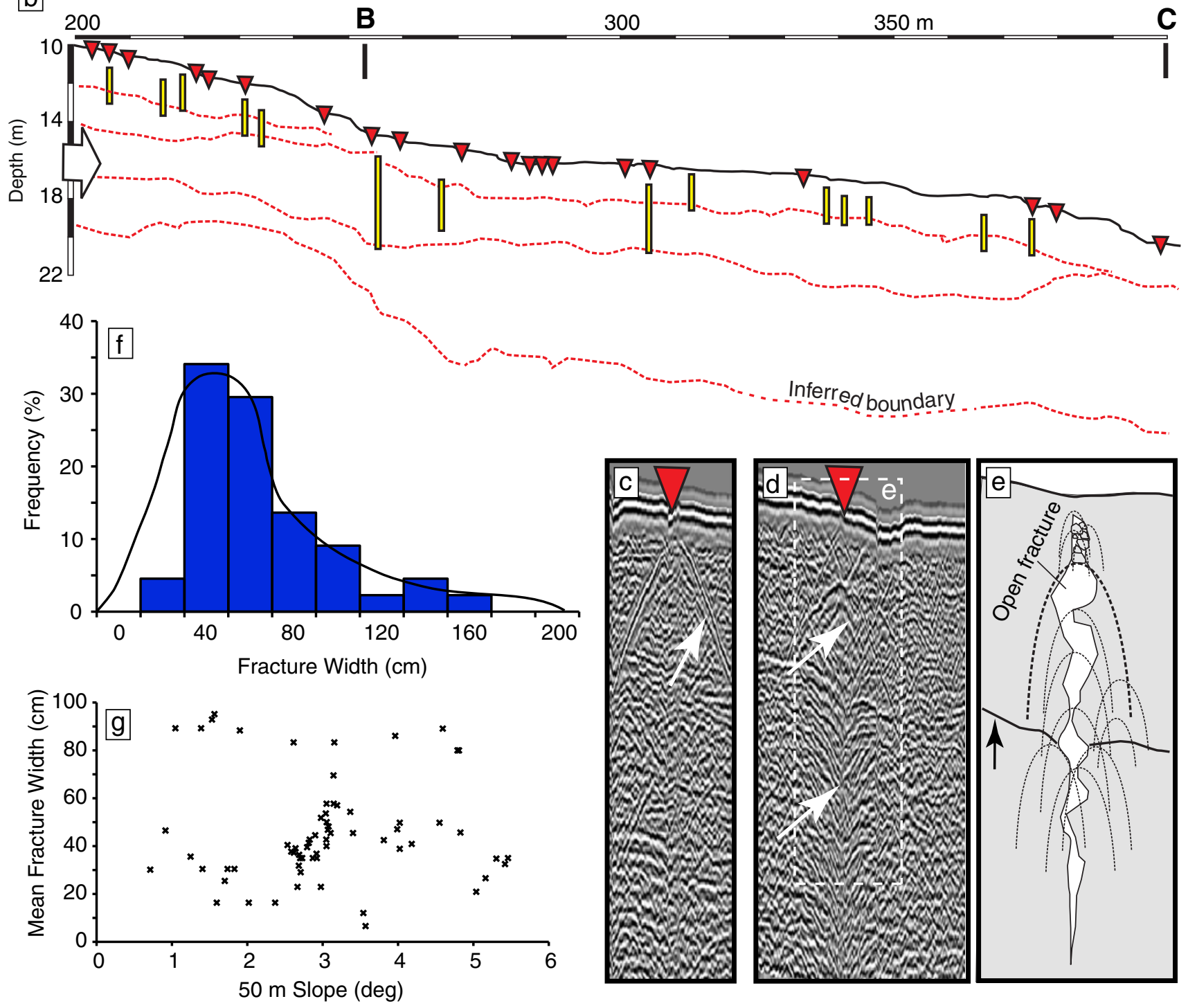


\section{Deposit temperature}

Between 25 January and 9 February 2009, 200 individual temperature measurements of the deposit were made using an Omega Instruments TJ72-CASS-140-36-CC thermocouple. The thermocouple rod was $1 \mathrm{~m}$ long and $0.5 \mathrm{~cm}$ diameter with a $3-\mathrm{cm}$-long sensor at the end. A series of vertical temperature profiles of the pumice flow deposits were measured with readings taken at depths of $0.1,0.4,0.7$, and $1 \mathrm{~m}$ for several traverses across the fan (Fig. 9a). An average temperature was calculated for each depth across the 30 locations sampled; those were compared with averaged temperatures for each depth across five control points within the adjacent Holocene scoria flow deposits (Fig. 9b, c). Before each vertical profile could be measured, a 1-m-long, 3-cm-diameter copper pipe was driven vertically into the deposit at each location, to enable insertion of the thermocouple. After the thermocouple was inserted, the pipe was slowly removed, when the temperature remained unchanged for $10 \mathrm{~s}$ it was recorded. The thermocouple was then withdrawn, pausing at $0.3 \mathrm{~m}$ increments to equilibrate and record temperatures, so that a vertical temperature profile through the uppermost part of the deposit was obtained. The precision of these measurements is considered to be on the order of twice the standard error on the mean of five ambient air temperature measurements $\pm 0.5^{\circ} \mathrm{C}$.

Temperature measurements were also obtained for the fractures. In these cases, it was unnecessary to use the pipe to allow for insertion of the thermocouple, and care was taken to ensure that the thermometer was in contact with the deposit and not simply air. Fracture temperatures, when compared to the adjacent deposit, indicate that there were at least two populations of fractures: those that were anomalously warm and those that were anomalously cold at depth. Most fractures measured fell into the first category and were $5^{\circ} \mathrm{C}$ to $10^{\circ} \mathrm{C}$ hotter, at $1 \mathrm{~m}$ below the surface, than the adjacent deposit. Anomalously cold fractures were rare and typically $\sim 5^{\circ} \mathrm{C}$ colder than the deposit. No obvious morphologic differences were noticed between the two.

\section{Radar interferometry and deposit deformation}

Methods

Thirty-nine InSAR interferograms were constructed using data obtained from the JERS-1 (L-band), ERS-1 and ERS-2 (C-band), and Envisat (C-band) radar satellites spanning the time intervals 1993-1994, 1995-2001, and 2003-2009,
Fig. 9 a Temperature measurements of deposit interior. Box color reflects temperature variation. b Comparison of breakout fan I temperatures (red diamonds) and those from the adjacent Holocene Tumbres scoria flow deposit (blue squares), which are used for a control. Error bars represent the standard error on the mean of all observations at that depth. Deposit temperatures are significantly warmer than the control and temperatures increase with depth. c Context map for measurement locations

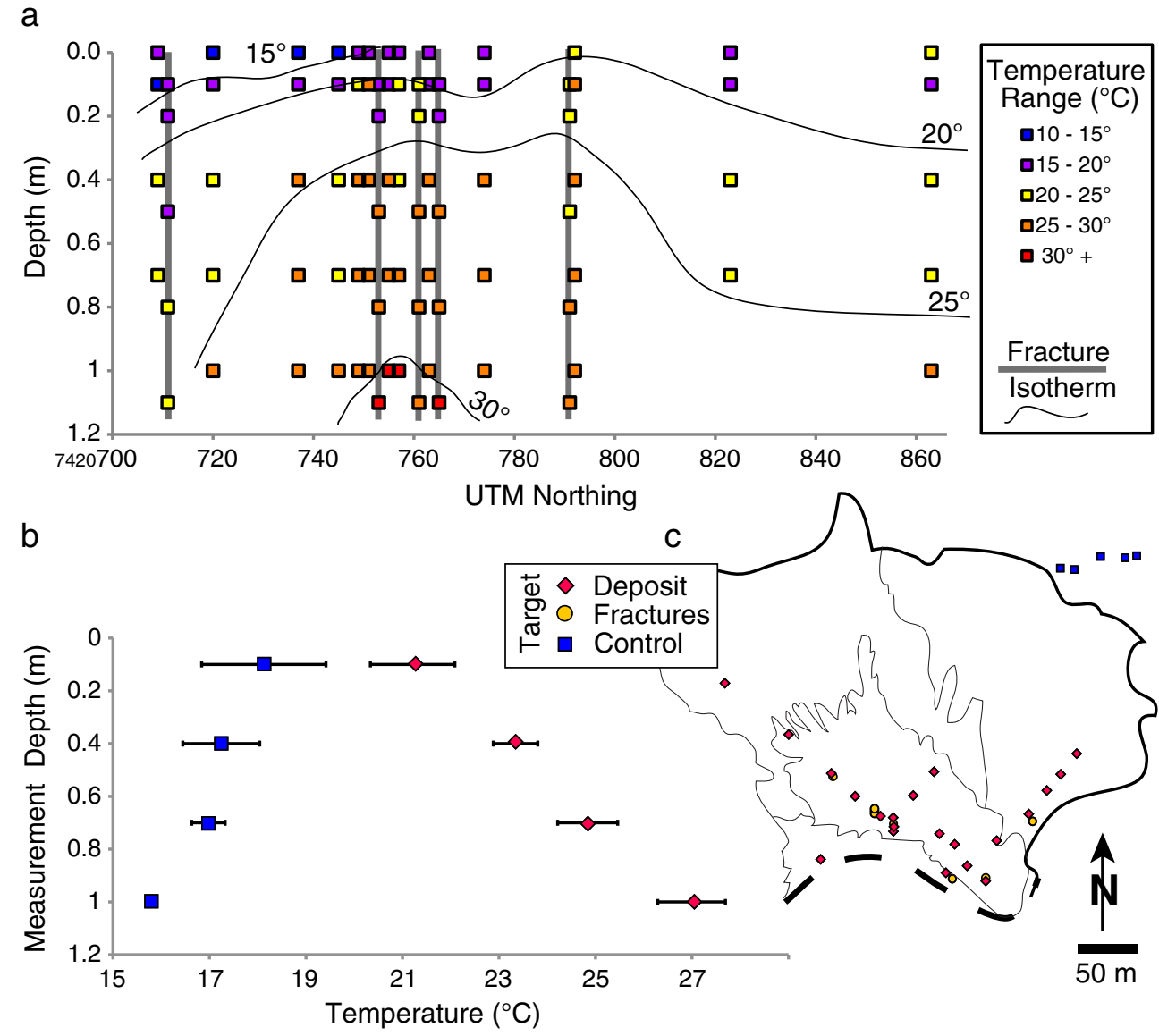


respectively. The Caltech/JPL ROI_PAC software was used for data processing (Rosen et al. 2004), and both the SNAPHU and Goldstein et al. (1988) algorithms were utilized to unwrap the interferograms (Chen and Zebker 2002; Goldstein et al. 1988). The time span of individual interferograms ranges from 1 month to 4 years (Online Resource 1). To remove topography from the InSAR phase, an aerial photogrammetric and GPS constrained digital elevation model (DEM) generated by Pavez et al. (2006) was merged with the SRTM DEM (e.g., Farr and Kobrick 2000) and interpolated at a resolution of $10 \mathrm{~m}$. The highresolution DEM is necessary to clearly discern the deformation; although many of the same interferograms were used by Pritchard and Simons (2002, 2004), they had a wider objective concerned with broad ground deformation in volcanic fields in the Andes; thus, they used a 90-m/pixel DEM, and hence, deformation associated with the pyroclastic flows was not observed. The Lascar region is located in favorable conditions for interferometric radar imaging due to its arid climate and lack of vegetation, resulting in highly coherent interferograms. However, in order to maintain high coherence at the full resolution of the interferograms, pairs with baselines greater than $200 \mathrm{~m}$ were not included in this analysis. We assume that all deformation occurs primarily in the vertical direction and convert the line-of-sight observations from each satellite (JERS $\sim 35^{\circ}$ and ERS/Envisat $\sim 23^{\circ}$ ) to represent vertical movement.

\section{Results}

The area of the deposit with the highest deformation is located where the deposit is considered (by the authors) to be the thickest, i.e., on the main fan overlying the andesite lava flow, about $6.5 \mathrm{~km}$ northwest of the summit (regions A and B of Fig. 10). Subsidence rates (Fig. 11) were calculated by averaging the deformation within $7 \times 7$-pixel boxes (Online Resource 2) and dividing by the time span covered by the two dates. The standard deviation of the deformation observed in a $7 \times 7$-pixel box provides an estimate of the error of the calculated subsidence rate. The location of this pixel box captures the region of highest deformation in most of the interferograms. A time series plot of the deformation rates for region A associated with each interferogram (Online Resource 3) has been generated (Fig. 11a). The 11 July 1993 to 1 April 1994 interferogram shows that within 1 year of emplacement, the deposit was subsiding at a rate of $\sim 1.1 \mathrm{~cm} /$ year. About 2 years after emplacement, the 8 July to 16 September 1995 interferogram shows that the deposit subsided at a rate of $\sim 2.4 \mathrm{~cm} /$ year (this high rate of deformation is considered short-lived, see below). Between 12 August 1995 and 19 May 1996, the subsidence rate decreased

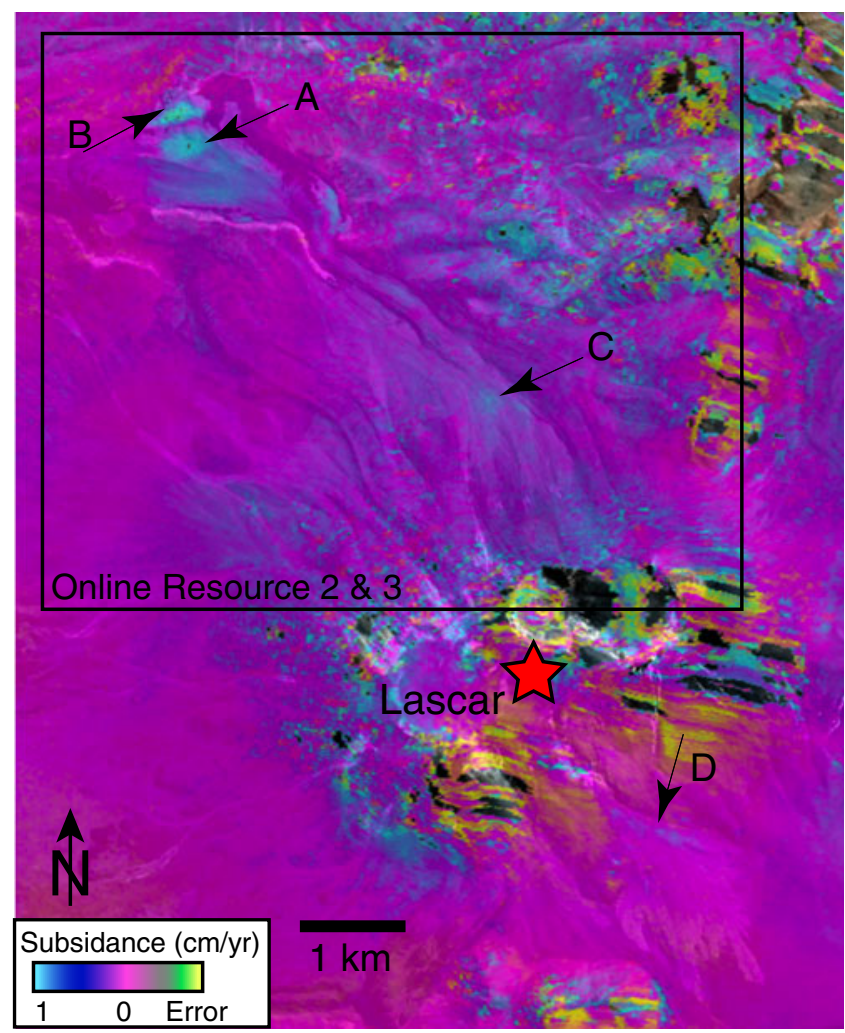

Fig. 10 Google Earth image overlaid with the 12 August 1995 to 19 May 1996 interferogram showing Lascar Volcano and at least four regions of pyroclastic flow deposit deformation. Blue shades represent negative deformation (subsidence) and purple represents no deformation. Gray regions were too noisy to be analyzed and regions of horizontal multicolored streaking are areas of interpolated data because of layover in the radar image. The box encompasses the approximate area represented in the images in Online Resources 2 and 3

to $\sim 0.8 \mathrm{~cm} /$ year. The average rate of subsidence from all the interferograms that span from 9 March 2003 to 14 October 2007 was $\sim 0.2 \mathrm{~cm} /$ year. Subsidence increased dramatically from 14 October to 18 November 2007 to a rate of $\sim 2.3 \mathrm{~cm} /$ year (again, a short-lived anomaly, see below). Elevated deformation rates continue until the 23 December 2007 to 26 April 2009 period, after which the rate returned to the pre-October/November 2007 rate of $\sim 0.2 \mathrm{~cm} /$ year. Total deformation in this region between 20 April 1993 and 26 April 2009 is estimated to be between 6 and $12 \mathrm{~cm}$ by using the error bars to bracket the lower and upper limits for the estimated subsidence rates and extrapolating to the date of the eruption.

Subsidence rates in region A also seem to show two sudden, isolated increases that are concurrent with two large subduction zone earthquakes that occurred hundreds of kilometers to the west. The surprisingly high subsidence rate that is observed between July and September 1995 ( $\sim 2.4 \mathrm{~cm} /$ year, compared to $\sim 1.1$ and $\sim 0.8 \mathrm{~cm} /$ year before and after) may have been induced by the $M_{\mathrm{w}} 8.1$ Antofagasta earthquake on 30 July $1995 \sim 260 \mathrm{~km}$ west of 
Fig. 11 Time series plots of deformation rate versus time for regions A and B. Horizontal bars correspond to the time span of the interferogram while vertical bars represent error. a Red points indicate pairs that include subsidence following the 2007 earthquake. b, c The immediate effect of the earthquake has been removed from all points following the earthquake for regions $\mathrm{A}$ and $\mathrm{B}$, respectively. d A map showing the locations of the 1995 Antofagasta and the 2007 Tocopilla earthquakes with respect to Lascar
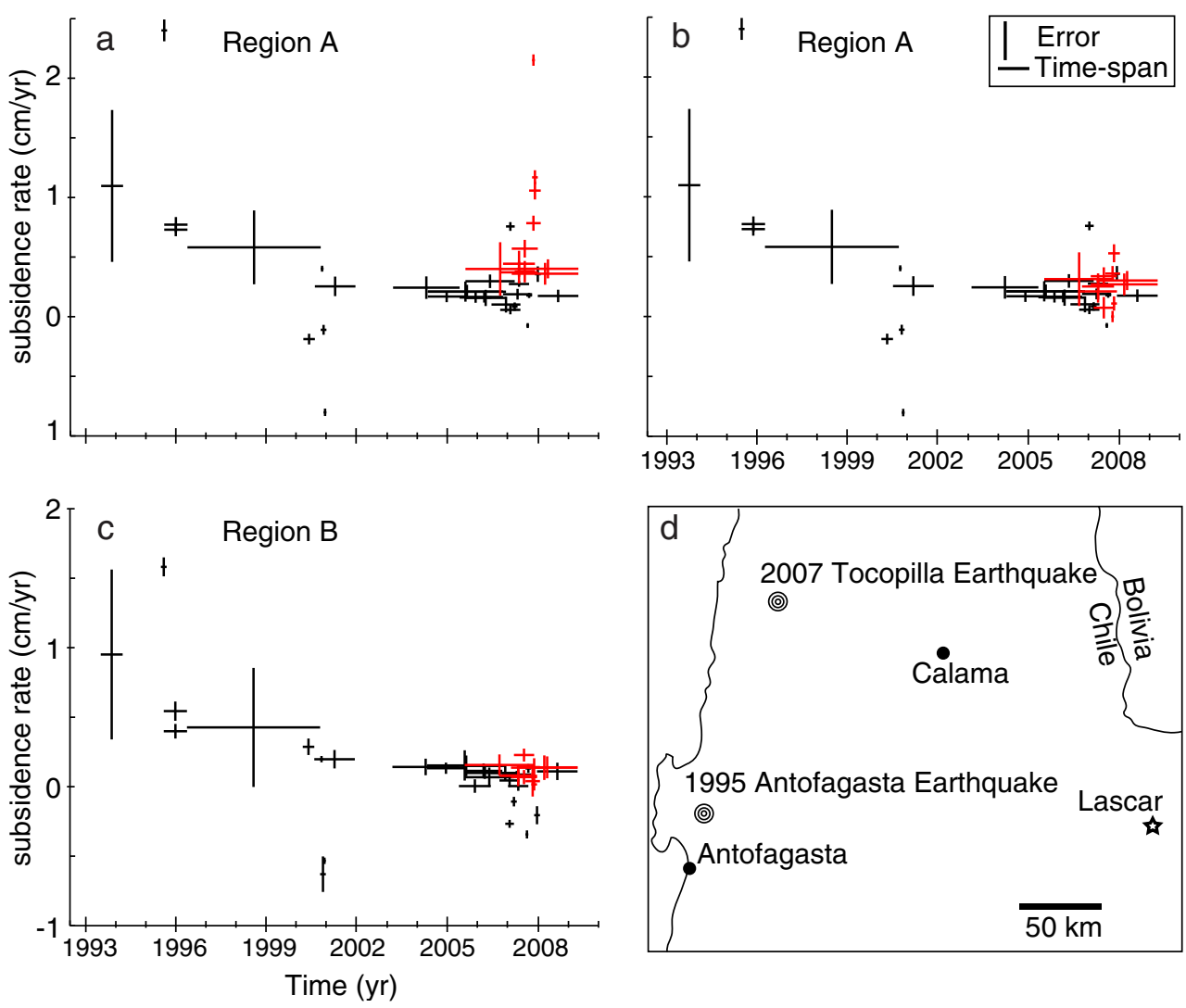

Lascar (Fig. 11 and Online Resource 3). Similarly, an abrupt jump in deformation rate is seen in interferograms that span the first half of November 2007 (Fig. 11 and Online Resource 2). A coherent subsidence pattern is seen to reappear after 7 years of little to no deformation of the deposit. Subsidence increased dramatically from 14 October to 18 November 2007 to a rate of $\sim 2.3 \mathrm{~cm} /$ year. This sudden increase in subsidence can likely be attributed to the $M_{\mathrm{w}} 7.7$ Tocopilla earthquake that occurred on 14 November $2007 \sim 255 \mathrm{~km}$ northwest of Lascar (Fig. 11 and Online Resource 3). When the subsidence associated with the earthquake (i.e., total deformation measured by the 14 October to 18 November 2007 interferogram) is subtracted from all the interferograms that include the earthquake, the average deformation rates post-2003 before and after the earthquake are both $\sim 0.2 \mathrm{~cm} /$ year (Fig. 11). Thus, the data are consistent with the earthquakes causing a very shortterm increase in subsidence (lasting minutes to maybe even weeks), with no discernable effect on the long-term deformation rate. An additional five earthquakes of $M 7.0$ or greater, however, occurred within $500 \mathrm{~km}$ of Lascar between 18 April 1993 and 26 April 2009, two of which are spanned by an interferogram, but these did not produce significant observable subsidence. The two events that could have been captured by the data are the $M 7.2$ earthquake on 12 May 2000 and the $M 7.8$ Tarapacá earthquake on 13 June 2005.
Breakout fan I (region B in Fig. 10) displayed subsidence in the first few years after emplacement, after which the deformation pattern disappears or becomes inconsistent (Online Resource 3). Due to the higher level of noise in the JERS interferogram, the 11 July 1993 to 1 April 1994 interferogram is not coherent in this region, so a measurement cannot be made during this time span. The three interferograms spanning 1995 and 1996 each show subsidence of about $\sim 1 \mathrm{~cm} /$ year for this region.

Another area of the deposit located closer to the summit (region $\mathrm{C}$ in Fig. 10) also shows a deformation pattern, although not as consistent and prominent as the areas described above. Between 11 July 1993 and 1 April 1994, the deposit was subsiding at a rate of $\sim 1.0 \mathrm{~cm} /$ year. About 2 years after emplacement, the 8 July to 16 September 1995 interferogram shows that the deposit subsided at a rate of $\sim 1.6 \mathrm{~cm} /$ year (again, this high rate is considered shortlived). Between 12 August 1995 and 19 May 1996, the subsidence rate decreased to $\sim 0.4 \mathrm{~cm} /$ year. The average rate of subsidence from all the interferograms that span from 9 March 2003 to 14 October 2007 was $\sim 0.1 \mathrm{~cm} /$ year. Although remnants of the deposit have been mapped in region $\mathrm{C}$, thick accumulations of deposits are not known to exist in this area, so the cause of this deformation is somewhat unclear. Finally, the pyroclastic flow deposit at region D (Fig. 10), located $\sim 0.5 \mathrm{~km}$ southeast of Lascar, shows subsidence of $\sim 0.3 \mathrm{~cm} /$ year that can only be 
observed in the 4-year interferogram of 18 May 1996 to 14 October 2000.

\section{Discussion}

The observed fracturing, subsidence, and cooling patterns

The fracture network, which first appeared about a year after deposit emplacement and has continued to develop since, comprises a series of fractures that have propagated from the deposit surface down, transecting both longitudinal and vertical flow unit boundaries. The widest and most extensive of which also accommodate a small degree of down-slope slumping along the discontinuity they formed. The fractures tend to be strike parallel and closely distributed in the upper fan, which is steeper, and widely spaced forming a polygonal pattern on lower slopes. Although not strictly fumaroles, the fractures are pathways for diffuse degassing. The degassing is inferred to be largely water vapor, which could be sourced from percolating meteoric water (snow melt), but the characteristic smell of acid gasses and the vaporphase residues on the fracture walls suggest the potential to develop local induration.

The InSAR data show that since 1993, the deposit surface has been subsiding at a decreasing rate. The regions of maximum subsidence rate correspond to the areas of the thickest pyroclastic deposits and the most extensive fracture networks, i.e., regions A (e.g., Fig. 3a, e) and B (Figs. 3b-d and 4). Subsidence variations across the deposit might also be controlled by substrate lithology; region A was emplaced upon a blocky lava flow that has large void spaces into which unconsolidated ignimbrite can infiltrate, while region B (with lesser subsidence) was emplaced on sub-horizontal compacted ground. This effect might have been particularly important for the subsidence of region A associated with the regional earthquakes. Low subsidence in region $\mathrm{D}$ cannot be explained by these factors (the deposit thickness is considered in the same range as $\mathrm{A}$ and $\mathrm{B}$, and the substrate is similar to that of B). However, region D is $\sim 550 \mathrm{~m}$ higher in elevation with colder ambient conditions and received more snow after the eruption (Denniss et al. 1998). These weather conditions likely enhanced cooling and subsidence early, before 1993 when our InSAR measurements began.

The exact mechanism by which the 1995 and 2007 earthquakes induced subsidence of the pyroclastic flow deposit cannot be concluded from this work; however, shaking seems to be important and this is an arid environment, so we suggest that physical compaction by grain reorientation into a more densely packed configuration is the likely cause. Further, in areas where the 1993 deposits are underlain by blocky lava, settling into fractures and voids may also have also accommodated subsidence. Although subsidence of young lava flows associated with a sequence of $M_{\mathrm{w}} 6$ earthquakes has previously been observed in Hawaii (Poland 2010), this is the first clear evidence of subsidence in pyroclastic flow deposits triggered by earthquakes.

We now consider, in turn, three possible mechanisms to generate the observed fracturing and subsidence: (a) deposit-scale extension, (b) cooling and thermal contraction, and (c) shrinkage by granular compaction. These mechanisms are not required to be independent. The potential role of each mechanism is reviewed, quantified where possible, and discussed in terms of potential contribution to the Lascar features.

\section{Deposit-scale extension}

Deposit-scale extension leading to fracturing could occur, from either mass wasting, slumping of the deposit, or local tectonic processes. Mass wasting and/or slumping would generate fracturing by extension of the deposit in the downslope direction. If this were the case, we could anticipate that fracture widths and orientations would correlate with direction and steepness of slope, fracture openings being widest where substrate slope was the greatest and fracture opening perpendicular to slope or sense of motion of the mass. Our data show (Figs. 2 and 4) that near the apex of the fan (where substrate slope is considered to be the highest), fractures are preferentially perpendicular to slope. Conversely, away from the fan apex, the fractures have three or four preferential orientations and form a polygonal fracture network (Fig. 4). Furthermore, fracture opening width is independent of slope steepness (Fig. 8g). This suggests that while slope has an effect on the orientation of fractures, substrate slope alone is not responsible for the generation of the fractures. We consider that this, as well as the lack of any other evidence to support slumping or creep, suggests that it is unlikely that slow mass movement is responsible for the fracture network.

Regional tectonics could cause fracturing in the deposit by deforming the substrate along faults and forcing the deposit to compensate. Fractures, in this case, would be focused along a discrete region of deformation (related to the fault zone) and extend onto the adjacent deposits. Fracture orientations in this case ought to relate to regional principal stresses. Furthermore, recent regional deformation would be observable in the InSAR interferograms. While the fracture network is not ubiquitous, it is also not concentrated in any discrete zone (Fig. 4), nor is it aligned with the regional $\sim \mathrm{E}-\mathrm{W}$ compressional stresses (Jordan et al. 1983), nor does it extend into other adjacent unconsolidated deposits. Moreover, subsidence observed in the InSAR 
interferograms is limited to the fresh deposits, almost exclusively.

\section{Cooling and thermal contraction}

The Lascar deposit accumulated sufficiently rapidly (36 h) to be considered a simple cooling body (as defined by Smith 1960; Wilson and Hildreth 2003). Based on observations of somewhat similar deposits at Soufrière Hills volcano (Fig. 12), estimates for initial temperatures for silicic to basaltic andesite clasts are in the order 600 $700^{\circ} \mathrm{C}$, although final emplacement temperatures might have been a few hundred degrees cooler, due to entrainment and cooling in the column and flow, respectively (i.e., 300$700^{\circ} \mathrm{C}$ ). A few days after the eruption, the Lascar deposit surface was $>100^{\circ} \mathrm{C}$ and 35 days after was still $>30^{\circ} \mathrm{C}$ (Gardeweg and Medina 1994). Gardeweg and Medina (1994) inferred that because of the relative thinness of the deposit (where they could access it, it was only $2 \mathrm{~m}$ thick) that the deposit surface finally cooled to ambient temperatures within 2 months. However, a near infrared image from the Japanese Earth Observation satellite (JERS-1) taken on 19 July 1993 shows that the Lascar edifice is partially snow covered except on the area of thick pyroclastic flow deposits (Denniss et al. 1998). The lack of snow indicates that almost 3 months after emplacement, the deposits still have enough residual heat to preclude snow buildup or to cause partial snow melt/sublimation. In addition, Landsat Thematic Mapper and Along Track Scanning Radiometer data collected following the emplacement of the Lascar flows (Wooster 2001) indicate that the surfaces of the north and south lobes actually took 8 to 12 months to cool to ambient.

Our observations substantiate that the northern lobe is still not fully cooled (Fig. 9). To estimate the temperature profile at depth, we used the Wallace et al. (2003) model for a conductively cooling pyroclastic layer, modified for two layers (the pyroclastic flow deposit and the substrate). The solution assumes a fixed temperature at the surface of the flow deposit, an initial temperature of the substrate that heats up with time and heat loss to the atmosphere. Wallace et al. (2003) show that this model approximates the temperature evolution measured within the pyroclastic flow deposits at Mt. St. Helens by Ryan et al. (1990). We assume values for the thickness of the pyroclastic deposit (30 m maximum for region $\mathrm{B}$ ), thermal conductivity ( 3 to $4 \mathrm{e}^{-}-7 \mathrm{~m}^{2} / \mathrm{s}$; from Ryan et al. 1990$)$, the air temperature $\left(0^{\circ} \mathrm{C}\right)$, initial ground temperature $\left(0^{\circ} \mathrm{C}\right)$, and initial pyroclastic flow temperature $\left(300-700^{\circ} \mathrm{C}\right)$. We compute the temperature evolution as a function of depth (every $10 \mathrm{~cm}$ ) to a depth of $20 \mathrm{~m}$ into the substrate every month for 17 years following the eruption (Fig. 13a). The computed temperature profile for 17 years post-emplacement cooling is compared to the measured data (Fig. 13c). The model and observed data agree within a $90 \%$ confidence interval (determined by $F$ test) but diverge below $0.75 \mathrm{~m}$, suggesting the deposit has cooled, perhaps aided by fractures, somewhat more than the model predicts.

The estimated cooling can be used to determine the subsidence expected by thermal contraction. The temperature change each month was determined, and the total delta temperature integrated along with a coefficient of thermal
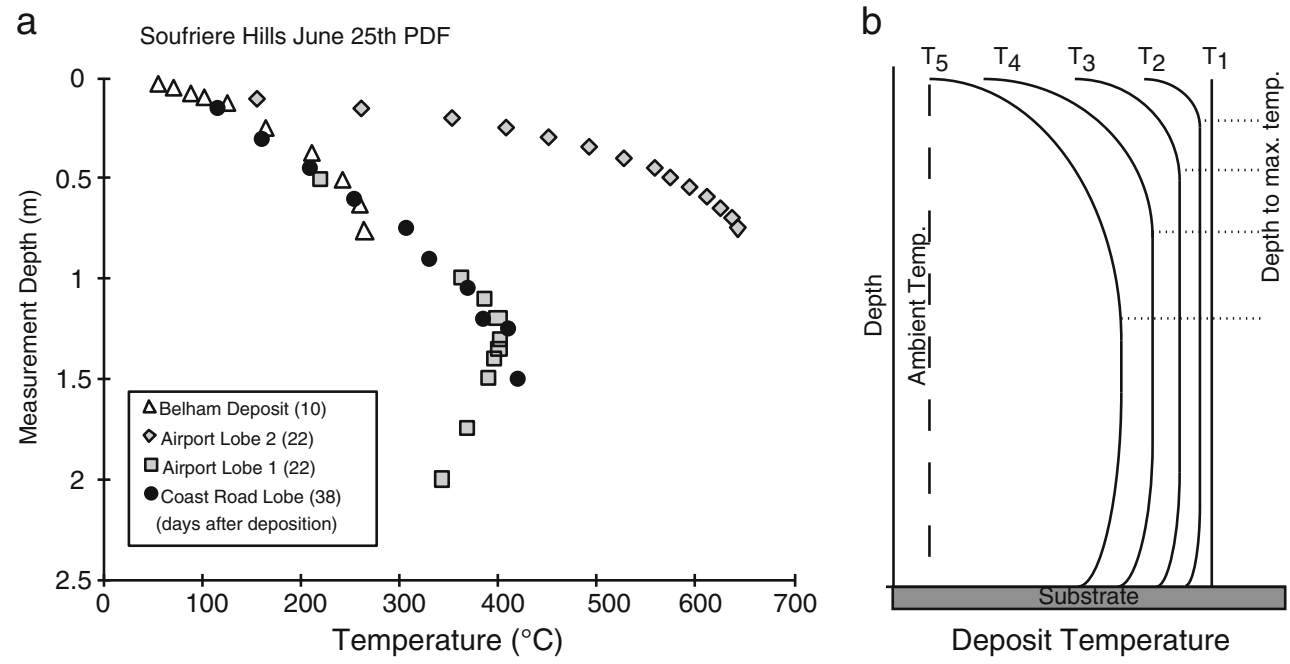

Fig. 12 a Previously unpublished data of deposit temperatures from the 25 June 1997 block-and-ash flow deposit from Soufriere Hills Volcano, Montserrat. The data show the interior temperature profiles of three different lobes from the same eruption measured over the 10 38-day period post-eruption. Note: airport lobe 1 (gray squares) is less than $5 \mathrm{~m}$ thick, where measured, and is likely showing cooling against the ground. The Lascar deposits likely had similar temperature profiles soon after they were deposited. b A conceptual model of the downward migration of the depth to maximum temperature. The maximum temperature is now likely to be very near the center of the deposit 
a

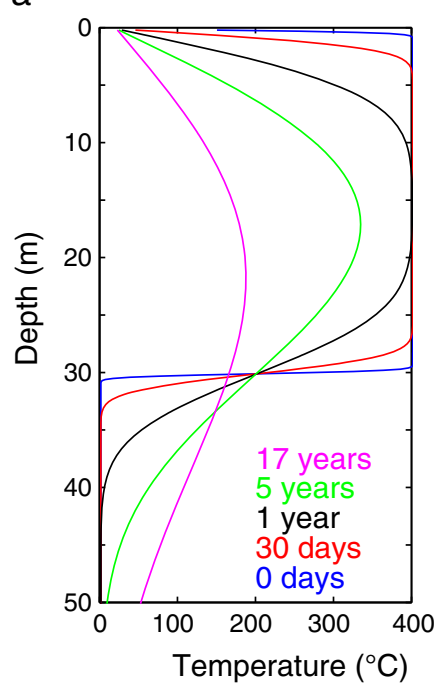

b

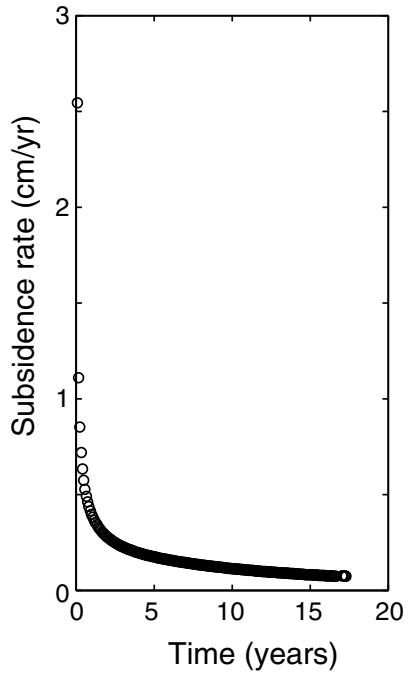

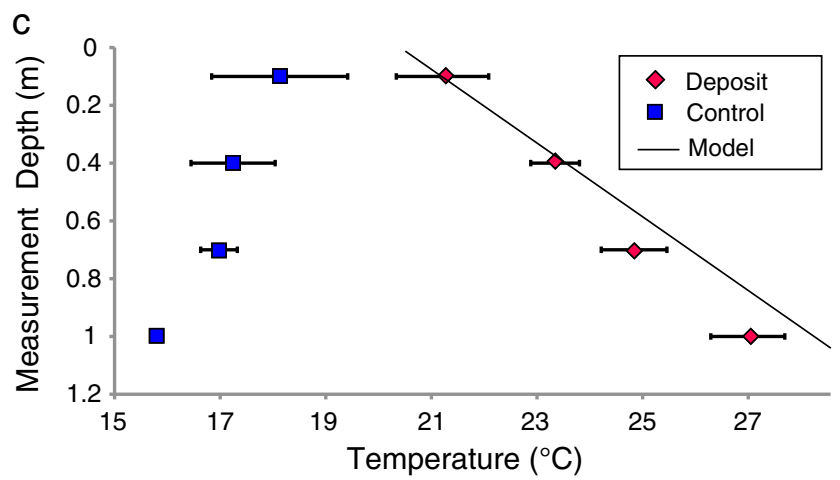

Fig. 13 Model predictions for thermal conductive cooling and contraction based on the two-layer, one-dimensional, analytic model of Wallace et al. (2003). The initial deposit temperature was taken to be $400^{\circ} \mathrm{C}$. a Temperature profiles as a function of depth at different times after the deposit was emplaced. b Magnitude of modeled subsidence as a function of time following the emplacement of the deposit. c A comparison of measured deposit temperatures (diamonds and squares) and modeled temperatures, for the top $2 \mathrm{~m}$ of the deposit

expansion $\left(8 \times 10^{-6} / \mathrm{K}\right.$; Ciancia 2006) to estimate the expected subsidence in each time interval. An example calculation showing the rate of subsidence declining with

time is shown in Fig. 13b. While several parameters in the model are not well constrained (e.g., initial temperatures of the pyroclastic flow or ground), the results, given a range of plausible parameters, provide a maximum subsidence rate of a few centimeters per year and show how the rate decays to a fraction of a centimeters per year after about 10 months. The modeled maximum rate of subsidence and the deceleration of the subsidence rate are within a factor of 2 or so of the observed subsidence rates (Fig. 11 and Online Resource 2) (except in the interferograms spanning the large earthquakes). This indicates that deposit thermal contraction could be a significant contributor to the observed subsidence.

We can also determine if the cooling and subsequent contraction of the deposit could produce the observed strain manifest by the fracture network. Linear strain can be expressed simply as:

$e=\left(l_{t}-l_{\mathrm{o}}\right) / l_{\mathrm{o}}$

where $e$ is extension, $l_{\mathrm{o}}$ is the un-deformed length, and $l_{t}$ is the length at time $t$. Negative extension is contraction, and $e=0.5$ means $l_{t}$ is $50 \%$ larger than $l_{\mathrm{o}}$. There are two possible approaches that can be taken based on assumptions about how the deposit has deformed (Table 2). Firstly, if it is assumed that the fractures are formed by deposit extension and thus that the deposit footprint has increased, then $l_{\mathrm{o}}$ can be found by subtracting the sum of fracture widths (along a single direction, $x$ ) from the present day deposit dimension, $l_{X}$ along the same direction (thus $l_{X}=l_{t}$ ). A caveat of estimating strain in this manner is the inherent assumption that the material properties remain constant, and yet in gradually deaerating and compacting pyroclastic material, this is clearly not the case. Consider for example desiccation cracks in mud, where the footprint of the mud remains roughly the same and changing the material properties forms the cracks. Following this, we take into account a second scenario that the present day deposit dimension, $l_{X}$, is the same as the original dimension, i.e., $l_{\mathrm{o}}$, and that the extent of deformation can
Table 2 Summary of parameters used in Eqs. 1 and 3 to find the deformed length

\begin{tabular}{|c|c|c|c|c|c|c|c|}
\hline \multirow[t]{2}{*}{ Transect } & \multirow[t]{2}{*}{ Heading } & \multirow[t]{2}{*}{ Relation to slope } & \multirow[t]{2}{*}{$l_{x}(m)$} & \multicolumn{2}{|c|}{$\sum_{X} \frac{w_{\mathrm{S}}}{\alpha}(m)$} & \multirow[t]{2}{*}{$l_{X}-\sum_{X} \frac{W_{\mathrm{S}}}{\alpha}(m)$} & \multirow[t]{2}{*}{$e$} \\
\hline & & & & $\alpha=3$ & $\alpha=12$ & & \\
\hline \multicolumn{6}{|c|}{ Scenario 1: assume deposit expansion $\left(l_{x}=l_{t}\right)$} & $l_{\mathrm{o}}$ & $l_{x}=l_{t}$ \\
\hline $\mathrm{A}-\mathrm{C}$ & 322 & Parallel & 390 & 8.01 & 2.00 & $385 \pm 3$ & $0.013 \pm 0.008$ \\
\hline D-E & 330 & Parallel & 230 & 4.04 & 1.01 & $227.5 \pm 1.5$ & $0.011 \pm 0.007$ \\
\hline $\mathrm{F}-\mathrm{G}$ & 240 & Perpendicular & 190 & 4.55 & 1.14 & $187 \pm 2$ & $0.015 \pm 0.009$ \\
\hline \multicolumn{6}{|c|}{ Scenario 2: assume deposit contraction $\left(l_{x}=l_{\mathrm{o}}\right)$} & $l_{t}$ & $l_{x}=l_{\mathrm{o}}$ \\
\hline $\mathrm{A}-\mathrm{C}$ & 322 & Parallel & 390 & 8.01 & 2.00 & $385 \pm 3$ & $-0.013 \pm 0.008$ \\
\hline D-E & 330 & Parallel & 230 & 4.04 & 1.01 & $227.5 \pm 1.5$ & $-0.011 \pm 0.007$ \\
\hline $\mathrm{F}-\mathrm{G}$ & 240 & Perpendicular & 190 & 4.55 & 1.14 & $187 \pm 2$ & $-0.015 \pm 0.009$ \\
\hline
\end{tabular}


be found by subtracting the sum of the fracture widths from $l_{X}$ (thus $l_{X}=l_{\mathrm{o}}$ ). We follow through the calculations for both scenarios but favor the latter as a more plausible scenario due to absence of evidence for deposit-scale extension (see "Deposit-scale extension").

Direct measurements of fracture width at depth $\left(W_{\mathrm{D}}\right)$ can only be obtained when the interior of the fracture is exposed in a trench; therefore, we approximate these dimensions using the relationship of a few observed fractured widths with surface trough width $\left(W_{\mathrm{S}}\right)$ by:

$W_{\mathrm{D}}=\frac{W_{\mathrm{S}}}{\alpha}$

where $\alpha$ (the ratio of fracture width on the surface to fracture width at depth) ranges from 3 to 12 based on field measurements where trenches were dug.

Therefore, for scenario 1 (assumed deposit extension), $l_{x}=l_{t}$ and $l_{\mathrm{o}}$ can be found by:

$l_{\mathrm{o}}=l_{X}-\sum_{X} \frac{W_{\mathrm{S}}}{\alpha}$

and for scenario 2 (assumed deposit shrinkage), $l_{x}=l_{o}$, and $l_{t}$ can be found by:

$l_{t}=l_{X}-\sum_{X} \frac{W_{\mathrm{S}}}{\alpha}$

Appropriate measurements of trough widths were taken along three transects: from A-C, D-E, and F-G (Fig. 4d). $\mathrm{A}-\mathrm{C}$ and $\mathrm{D}-\mathrm{E}$ are flow direction and slope parallel, while $\mathrm{F}-\mathrm{G}$ is perpendicular to $\mathrm{D}-\mathrm{E}$ and therefore transverses to flow direction. Table 2 summarizes $l_{X}, l_{\mathrm{o}}, l_{t}$, and $e$ for all three transects for both scenarios above. For the extension scenario, the fractures represent between $1.1 \%$ and $1.3 \%$ extension of the northern lobe in the slope parallel direction and $1.5 \%$ extension in the traverse slope. Conversely, for the shrinkage scenario, the fractures imply material shrinkage of $1.1-1.3 \%$ in the slope parallel direction and $1.5 \%$ in the traverse slope direction. Both sets of results indicate that the slope itself does not play an important role in fracture opening.

Given that the deposits are cooling, we can now consider the expected change in length of a body due to thermal contraction and compare that to the 1.1-1.5\% measured shrinkage (as above). The extent of thermal contraction, $l_{\mathrm{c}}$, can be expressed as (Weast 1974):

$l_{\mathrm{c}}=l_{\mathrm{o}}(1+a T)$

where $a$ is the coefficient of thermal expansion and $T$ is the temperature at time $t$ (taken as $700^{\circ} \mathrm{C}$ ) and negative expansion is contraction. From laboratory experiments, Ciancia (2006) found that the mean coefficient of thermal expansion of a cooling non-welded ignimbrite (The Painted
Tuff, Yucca Mountain, Nevada) is between 5 and $8 \times 10^{-6} / 0$ C. Using Eq. 5, we find that cooling may have caused contraction of between 0.004 and $0.006(0.4-0.6 \%$ contraction), a factor of 2-3 less shrinkage than observed (Table 2). We infer, therefore, thermal contraction alone is not responsible for the observed strain and fracture network. As the deposits are not fully cooled, it is plausible, however, that thermal contraction is continuing to open fractures and contribute to subsidence.

Finally, the presence of water greatly influences cooling conditions and timescale. Dry conditions in the substrate, as thought to be the case for the northwestern fan at Lascar, would produce a conduction-dominated cooling regime (Keating 2005) at the base of the deposit. However, during the eruption, distal lobes of the flow to the northwest dammed the stream within the Quebrada Talabre at Tumbres. Because of the high permeability of the deposit, the water reappeared again days to weeks after the eruption, re-establishing the hydrologic system (Gardeweg and Medina 1994). This water source likely had a local chilling effect on a volumetrically minor section of the deposit in the northwest.

\section{Granular compaction}

Newly emplaced ash-rich pyroclastic material has low yield strength and is easily remobilized. The deposit surface underfoot, can be readily fluidized to loose, and can have insufficient bearing capacity to support the weight of a person for weeks after emplacement (e.g., Wilson and Head 1981). Compaction begins to affect pyroclastic flow deposits, from the moment of emplacement, through geological time. Sheridan and Wang (2005) summarized the processes (and approximate time scales) as follows: (1) deflation of any turbulent and/or fluidized bed (seconds), (2) degassing of stationary fluidized bed (seconds-days), (3) mechanical compaction by rotation and compression of particles without change in their shape (years), and finally (4) compaction, including particle shape change, and welding (years). Experimental work by Druitt et al. (2004, 2007) shows that during the evacuation of gas, fluidized pyroclastic material loses half of its thickness within minutes and that the gas retention capacity is proportional to ash fraction. We infer that at the natural scale, deaeration is controlled by gas permeability operating over the timescale of days to weeks. Further compaction and reduction of void space occurs in response to load stresses (Wilson and Hildreth 2003), and thus, it is also reasonable to infer that compaction is greatest at, or near, the base of the deposit and progresses upward with time. After a closely packed granular organization has been reached, limited deformation would follow unless grains deform. 
Compaction has already been inferred as the origin of large-scale deposit features (i.e., slumping, surface depressions, and faults) and fractures formed as the material properties transform from behaving as a ductile granular material to a brittle solid (Keating 2005). The Lascar fractures indicate that the deposit was sufficiently compacted to deform brittlely within a year of emplacement. The polygonal distribution of the fractures is reminiscent of desiccation cracks commonly affecting fine-grained sediments (e.g., Plummer and Gostin 1981; Cartwright and Dewhurst 1998). We suggest that here the small volume changes (shrinkage) associated with deaeration, compaction, and cooling to have resulted in a comparable process.

Conceptual model for post-depositional subsidence and fracture formation

We propose a conceptual model that includes three processes acting over contrasting but somewhat overlapping timescales that are inferred to produce the observed subsidence patterns, fracture network, and cooling trends of the 1993 deposit. During the final stages of transport and for the first few minutes after emplacement, the pumice flow deposits underwent rapid deaeration, with a large (possibly $>50 \%$ ) loss in volume. During this phase, the fluidized to incipiently fluidized deposit would have adjusted ductilely; therefore, associated deformation is not preserved. Most of the gas was probably displaced by the settling particles within the first few hours when the deposits were loose, and gas permeability was high, but likely continued at a much lower rate for days to weeks.

Deaeration and granular compaction form a continuum through which the deposit changes from deforming ductilely to brittlely. During deaeration, the grains settle and form a very loosely packed configuration, perhaps with few point contacts between the grains, which, with minimal disturbance, can break so that the material re-fluidizes. Granular compaction can involve grain reorientation, so that the contact network between the grains becomes denser and void space is reduced (analogous to a shift from cubic to tetrahedral packing of spheres; e.g., White and Walton 1937). Once this situation has been reached, it is likely difficult, but not impossible (e.g., Torres et al. 1996) to refluidize the material. The brittle deformation observed accounts for $\sim 3 \%$ volume change, half of which cannot be accounted for by thermal contraction and is therefore inferred to be compaction-related.

Throughout this period, the deposit is also cooling through combined conduction of heat into the substrate and radiation into the atmosphere (Fig. 14). Assuming an emplacement temperature of $\sim 700^{\circ} \mathrm{C}$, a further $\sim 1 \%$ of deposit volume would have been lost by thermal contraction over the following 17 years (Fig. 13). The rate of both
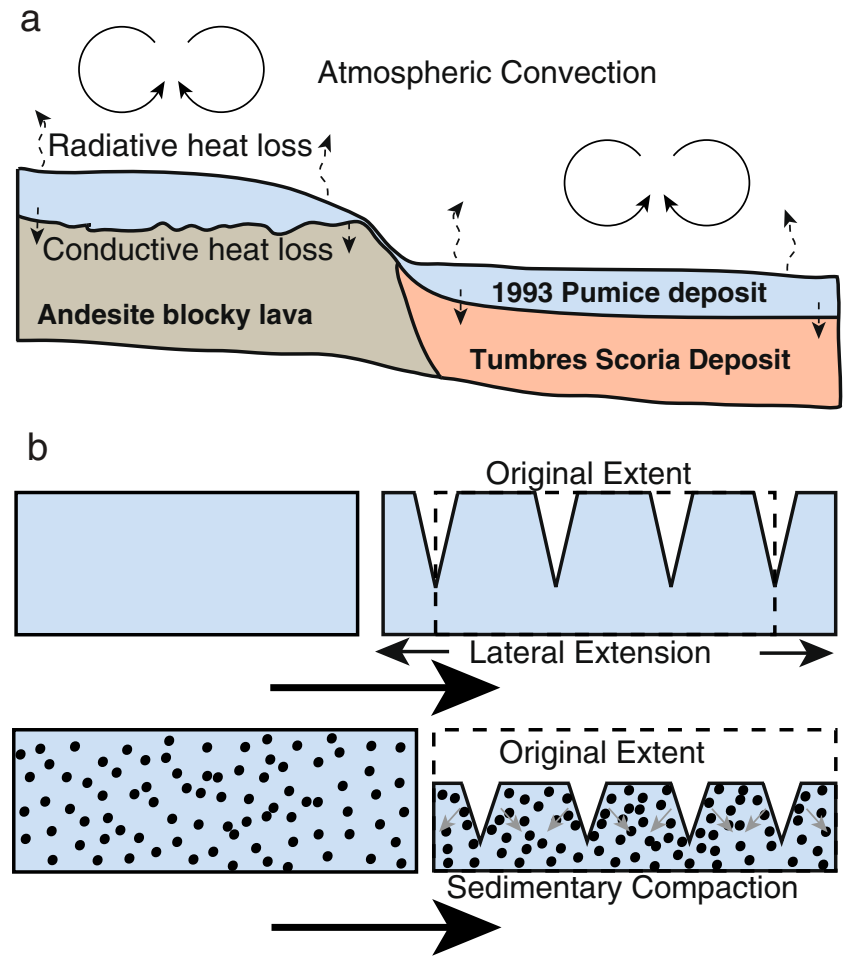

Fig. 14 a A simplified cartoon illustrating of the modes of heat transfer from the deposit after emplacement. While radiation, atmospheric convection, and conduction all contribute to cooling the deposit, conduction is likely rate limiting in the days to weeks postemplacement (Wallace et al. 2003). b A simplified cartoon representing two possible modes of deformation: lateral extension and sedimentary compaction. The observed subsidence and lack of strong evidence to support deposit slumping or creep leads us to favor contraction or shrinkage by deaeration and compaction for the formation of the fracture network

cooling and deformation was the highest soon after emplacement (Figs. 11 and 13) and decayed thereafter. Although compaction, and to a lesser extent thermal contraction, must persist to this day, the indications are that these now occur at negligible rates.

Fractures in ignimbrites elsewhere

Fracturing has been reported in non-welded ignimbrites elsewhere: Two examples of which are the Grants Ridge Tuff (Keating and Valentine 1998) and the 273-ka Poris Formation, Tenerife (Brown and Branney 2004). Brown and Branney (2004) describe the features within the Poris Formation as clastic dikes because they were in-filled with pumiceous sand and silt derived from the overlying unit. These dikes extended up to $20 \mathrm{~m}$ in length and were observed to cut as much as $9 \mathrm{~m}$ into the ignimbrite with fracture widths up to $50 \mathrm{~cm}$ wide. The dike orientations were parallel to the strike of the paleo-slope, and their margins were straight to irregular. Brown and Branney (2004) therefore interpreted the clastic dikes as records of 
down-slope extensional deformation that occurred shortly after the eruption and which may have been triggered by aftershocks and fault readjustments following caldera collapse. Keating and Valentine (1998) likewise inferred faulting associated with seismic shaking as the origin of the fractures they observed in the Grants Ridge Tuff. Similar features have been found in various other deposits (Brown and Branney, personal communication) including the Acatlán ignimbrite (central Mexico), as well as ignimbrites of the La Pacana caldera (Fig. 15). We note that although the 1993 eruption at Lascar was accompanied by some seismicity $\left(M_{\mathrm{w}} 3\right.$, Guarinos and Guarinos 1993), seismic activity associated with the eruption decreased rapidly thereafter and is thought to have been at a low level ever since. Seismic induced fracturing is thus not considered a likely explanation for the Lascar fractures and does not explain the fracture patterns observed.

Parallels can also be drawn with other previously described isolated features in the literature such as fumarolic fractures in the Valley of Ten Thousand Smokes (VTTS) (Griggs 1922; Zies 1924; Keith 1991), fossil fumaroles in the Mazama ignimbrite (Williams 1942;
Bacon 1983), and fumarolic ridges observed in the Bishop Tuff(Sheridan 1970). In all three cases, fracture sets formed which were also utilized as preferential pathways for degassing. Many fractures within the VTTS ignimbrite, observed within 10 years of emplacement, exhibited a pseudo-polygonal network similar to those described here. Further, the wide fractures $(\sim 1 \mathrm{~m})$ in this thick deposit $(>150 \mathrm{~m})$ are also consistent with deposit shrinkage in the order of a few percent. Fumarolic ridges in the $\sim 700$-ka Bishop Tuff are preserved as positive relief features because precipitates indurated the fracture fill (Sheridan 1970). These ridges could also, therefore, be remnants of a once extensive network of compaction/cooling fractures.

Features within ignimbrites, such as fractures, clastic dykes, and fumarolic ridges, are often only observed in two dimensions. Although they are generally not well documented, they do appear to be relatively common. We suggest that the Lascar 1993 deposits provide evidence that their origin is associated with inherent, internally driven processes, by the post-depositional compaction and subsidence of initially inflated pyroclastic deposits, aided by the additional effect of thermal contraction, and that external
Fig. 15 Examples of fractures from other ignimbrites: $\mathbf{a}, \mathbf{b}$ the Acatlán ignimbrite (Central Mexico, photographs courtesy of M. Branney), c a La Pacana Caldera ignimbrite, and $\mathbf{d}$ block and ash flow deposit from Tumisa volcano, northern Chile
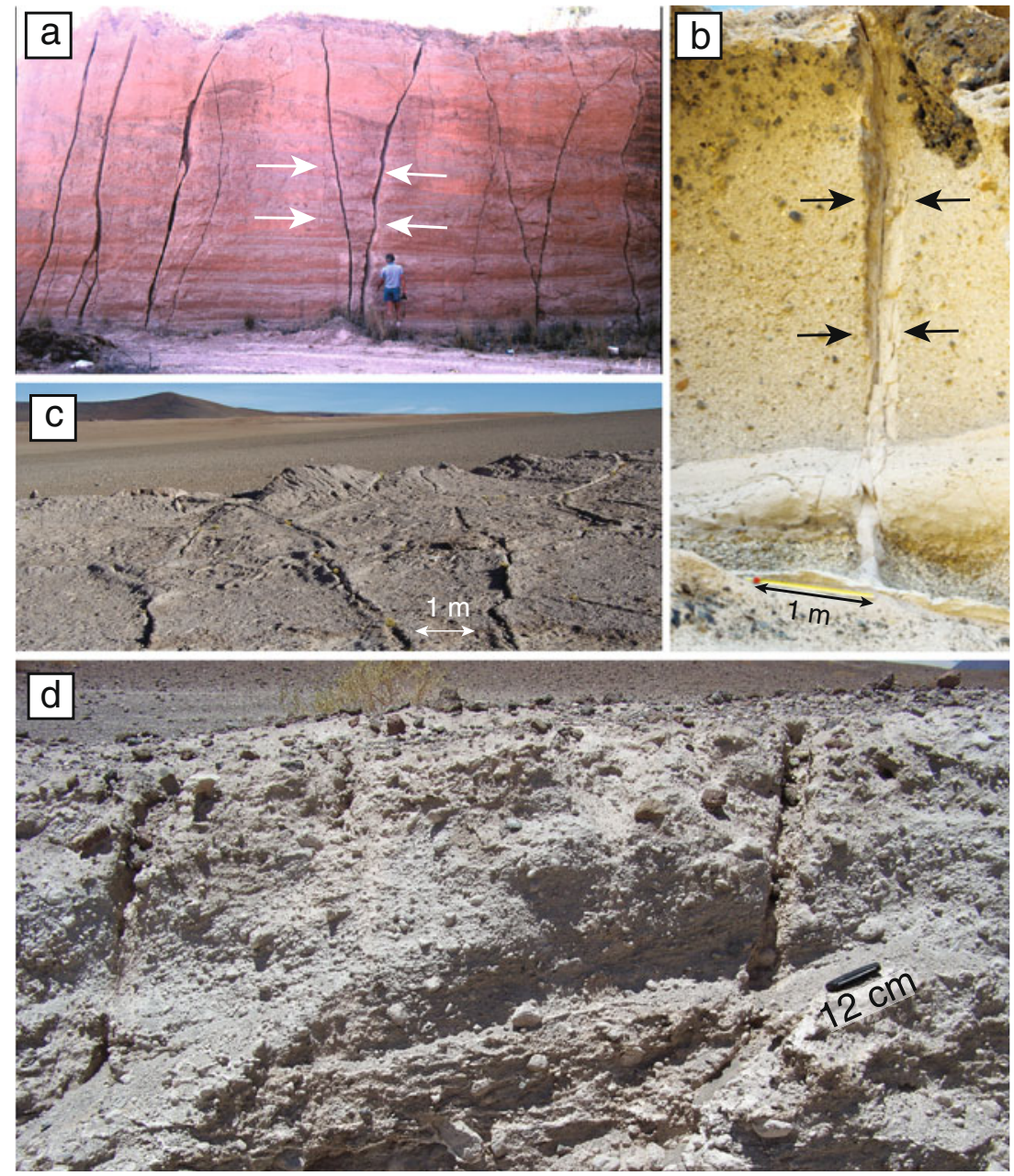
forces such as seismic shaking and slumping are not always required to explain their origin. Although clearly where these external factors do occur, the effect can be exaggerated as exemplified by the subsidence rate after the regional earthquakes.

\section{Conclusions}

1. The fractures and subsidence of the 1993 pyroclastic flow deposits formed in response to several processes: initial deaeration and subsequent compaction as well as thermal contraction.

2. The fracture network was first identified in April 1994 indicating that the deposit was sufficiently compact 1 year after emplacement to deform brittlely. Individual fractures are $\sim 40 \mathrm{~cm}$ wide, partially in-filled troughs at the surface, and $\sim 10 \mathrm{~cm}$ wide voids at depth. The network is not ubiquitous across the 1993 deposit; rather, it has developed in patches where the deposit is the thickest.

3. GPR has been demonstrated as an effective tool for imaging subsurface structures in pyroclastic deposit by providing images of the deep-seated fracture network within unconsolidated ignimbrite. The near-vertical fractures initiate at, or near, the surface and extend to depths of up to $10 \mathrm{~m}$.

4. As observed with InSAR, the 1993 deposits have been subsiding slowly since emplacement. Subsidence rates were initially high $(0.5$ to $1.5 \mathrm{~cm} /$ year $)$ within the first 2 years and decayed to $\sim 0.25 \mathrm{~cm} /$ year within a decade. Seismic shaking from two regional earthquakes located more than $100 \mathrm{~km}$ away is shown to have accelerated the rate of subsidence over short time periods. These data provide the first observations of InSARdetermined deposit deformation.

5. Such fractures can be expected in deposits from hot (for sufficient thermal contraction) and fluidized (for sufficient deposit expansion and subsequent settling) flows, where preservation in an arid environment allows for their unimpeded development. These processes are likely to have occurred elsewhere, but in the absence of information on their three-dimensional architecture and the associated ground deformation, their genetic origin may have been overlooked.

Acknowledgments P. Whelley is generously supported by a NASA Graduate Student Research Program Fellowship and a Geological Society of America Graduate Research Grant. The initial project was supported by a Royal Society of London Dorothy Hodgkin Fellowship and Royal Society of London Standard Grant to E. S. Calder, as well as a Royal Society Summer Studentship to S. Alcaraz. ERS/Envisat InSAR data were acquired under a Category 1 project from the European Space Agency, and JERS data are from the Remote Sensing
Technology Center of Japan. Cornell's contribution was supported by NASA grant NNX08ATO2G issued through the Science Mission Directorate's Earth Science Division. We thank F. Delgado and L. Wooler for support in the field and M. Bursik for use of the field thermometers. R. Brown and M. Branney are thanked for generously providing images and descriptions of fractures within the Poris Ignimbrite on Tenerife. We thank B. Ellis and G. Lube for thoughtful reviews.

\section{References}

Bacon CR (1983) Eruptive history of Mount Mazama and Crater Lake Caldera, Cascade Range, U.S.A. J Volcanol Geotherm Res 18:57-115

Bacon CR (2008) Geologic map of Mount Mazama and Crater Lake caldera, Oregon. US Geol Surv Sci Invest Map SIM I-2832, 1:24000 scale, 4 sheets and $45 \mathrm{p}$ text

Bailey JE, Self S, Wooller LK, Mouginis-Mark PJ (2007) Discrimination of fluvial and eolian features on large ignimbrite sheets around $\mathrm{La}$ Pacana Caldera, Chile, using Landsat and SRTM-derived DEM. Remote Sens Environ 108:24 41

Branney MJ, Gilbert JS (1995) Ice-melt collapse pits and associated features in the 1991 lahar deposits of Volcán Hudson, Chile: criteria to distinguish eruption-induced glacier melt. Bull Volcanol 57:293-302

Branney M, Kokelaar B (2002) Pyroclastic density currents and the sedimentation of ignimbrites. Geological Society of London, London, Memoir No. 27, p 152

Branney MJ, Barry TL, Godchaux M (2004) Sheathfolds in rheomorphic ignimbrites. Bull Volcanol 66:485-491

Brown RJ, Branney MJ (2004) Event-stratigraphy of a calderaforming ignimbrite eruption on Tenerife: the $273 \mathrm{ka}$ Poris Formation. Bull Volcanol 66:392-416

Calder ES, Sparks RSJ, Gardeweg MC (2000) Erosion, transport and segregation of pumice and lithic clasts in pyroclastic flows inferred from ignimbrite at Lascar Volcano, Chile. J Volcanol Geotherm Res Elsevier 104:201-235

Cartwright J, Dewhurst D (1998) Layer-bound compaction faults in fine-grained sediments. Geol Soc Am Bull 110:1242-1257

Cassidy NJ, Russell AJ, Marren PM, Fay H, Knudsen O, Rushmer EL, Van Dijk TAGP (2003) GPR derived architecture of November 1996 Jökulhlaup deposits, Skeiðarársandur, Iceland. In: Bristow SC, Jol MH (eds) Ground penetrating radar in sediments. Geological Society of London, special publication. Geological Society of London, London, pp 153-166

Cassidy NJ, Calder ES, Pavez A, Wooller LK (2009) GPR-derived facies architectures: a new perspective on mapping pyroclastic flow deposits. In: Thordarson T, Larsen G, Rowland SK, Self S, Hoskuldsson A (eds) Studies in volcanology: the legacy of George Walker. The Geological Society for IAVCEI, Bath, pp 181-210

Chen C, Zebker H (2002) Phase unwrapping for large SAR interferograms: statistical segmentation and generalized network models. IEEE Trans Geosci Remote Sens 40:1709-1719

Ciancia M (2006) Geotechnical properties of tuffs at Yucca Mountain, Nevada. In: Heiken G (ed) Tuffs their properties, uses, hydrology, and resources. Geological Society of America, Boulder, pp 33-89

Csatho B, Schenk T, Kyle P, Wilson T, Krabill W (2008) Airborne laser swath mapping of the summit of Erebus volcano, Antarctica: applications to geological mapping of a volcano. J Volcanol Geotherm Res 177:531-548

Denniss A, Harris A, Ro D (1998) Satellite observations of the April 1993 eruption of Lascar Volcano. Int J Remote Sens 19:801-821

Druitt TH, Bruni G, Lettieri P, Yates JG (2004) The fluidization behaviour of ignimbrite at high temperature and with mechanical agitation. Geophys Res Lett Am Geophys Union 31:L02604 
Druitt TH, Avard G, Bruni G, Lettieri P, Maez F (2007) Gas retention in fine-grained pyroclastic flow materials at high temperatures. Bull Volcanol Springer 69:881-901

Farr T, Kobrick M (2000) Shuttle radar topography mission produces a wealth of data. Am Geophys Union Eos 81:583-585

Gardeweg M, Medina E (1994) La erupción subpliniana del 19-20 de Abril de 1993 del volcan Lascar, N de Chile. Actas del 7 Cong Geol Ch 7:299-304

Gardeweg MC, Sparks RSJ (1998) Evolution of Lascar Volcano, northern Chile. J Geol Soc Lond 155:89-104

Goldstein RM, Zebker HA, Werner CL (1988) Satellite radar interferometry: two-dimensional phase unwrapping. Rad Sci 23:713-720

Gómez-Ortiz D, Martín-Velázquez S, Martín-Crespo T, Márquez A, Lillo J, López I, Carreño F (2006) Characterization of volcanic materials using ground penetrating radar: a case study at Teide volcano (Canary Islands, Spain). J Appl Geophys 59:63-78

Griggs RF (1922) The valley of ten thousand smokes. National Geographic Society, Washington

Guarinos J, Guarinos A (1993) Contribution a l'etude de l'eruption du Volcan Lascar (Chili) d'avril 1993. Arch Sci Geneve 46:303-319

Jordan TE, Isacks BL, Allmendinger RW, Brewer JA, Ramos VA, Ando C (1983) Andean tectonics related to geometry of subducted Nazca plate. Geol Soc Am Bull 94:341-361

Keating GN (2005) The role of water in cooling ignimbrites. J Volcanol Geotherm Res 142:145-171

Keating GN, Valentine GA (1998) Proximal stratigraphy and syneruptive faulting in rhyolitic Grants Ridge Tuff, New Mexico, USA. J Volcanol Geotherm Res 81:37-49

Keith T (1991) Fossil and active fumaroles in the 1912 eruptive deposits, Valley of Ten Thousand Smokes, Alaska. J Volcan Geoth Res 45:225-254

Lee C, Lu Z, Kwoun O, Won J (2008) Deformation of the Augustine Volcano, Alaska, 1992-2005, measured by ERS and ENVISAT SAR interferometry. Earth Planet Sci Lett 60:447-452

Major JJ, Janda RJ, Daag AS (1996) Watershed disturbance and lahars on the east side of Mount Pinatubo during the mid-June 1991 eruptions. In: Newhall CG, Punongbayan RS (eds) Fire and mud: eruptions and lahars of Mount Pinatubo, Philippines. Philippine Institute of Volcanology and Seismology, Quezon City, pp 895-919

Matthews S (1999) The Piedras Grandes-Soncor eruptions, Lascar Volcano, Chile; evolution of a zoned magma chamber in the central Andean upper crust. J Pet 40:1891-1919

Nocita B (1988) Soft-sediment deformation (fluid escape) features in a coarse-grained pyroclastic-surge deposit, north-central New Mexico. Sedimentology 35:275-285

Pavez A, Remy D, Bonvalot S, Diament M, Gabalda G, Froger L, Julien P, Legrand D, Moisset D (2006) Insight into ground deformations at Lascar Volcano (Chile) from SAR interferometry, photogrammetry and GPS data: implications on volcano dynamics and future space monitoring. Aperture 100:307-320

Pierson T, Janda R, Umbal J, Daag A (1992) Immediate and long-term hazards from lahars and excess sedimentation in rivers draining Mount Pinatubo, Philippines. U.S. Geol Surv Water Resour Invest Rep 92-4039

Plummer P, Gostin V (1981) Shrinkage cracks; desiccation or synaeresis? J Sed Res 51:1147-1156

Poland M (2010) Localized surface disruptions observed by InSAR during strong earthquakes in Java and Hawai'i. Bull Seismol Soc Am 100:532-540

Pritchard M, Simons M (2002) A satellite geodetic survey of largescale deformation of volcanic centres in the central Andes. Nature 418:167-171
Pritchard M, Simons M (2004) An InSAR-based survey of volcanic deformation in the southern Andes. Geophys Res Let 31:L15610

Riquelme R, Martinod J, Herail G, Darrozes J, Charrier R (2003) A geomorphological approach to determining the Neogene to Recent tectonic deformation in the Coastal Cordillera of northern Chile (Atacama). Tectonophysics 361:255-275

Rosen P, Hensley S, Peltzer G, Simons M (2004) Updated repeat orbit interferometry package released. Eos Trans AGU 85:47

Ross CS, Smith RL (1961) Ash-flow tuffs: their origin, geologic relations, and identification. US Geol Surv Prof Pap 366:81

Rowley PD, Kuntz MA, Macleod NS (1981) Pyroclastic-flow deposits. In: Lipman PW, Mullineaux DR (eds) The 1980 eruptions of Mount St. Helens, Washington. US Geological Survey, Washington, DC, pp 489-512

Russell J, Stasiuk M (1997) Characterization of volcanic deposits with ground-penetrating radar. Bull Volcanol 58:515-527

Ryan M, Banks N, Hoblitt R, Blevins JYK (1990) The in-situ thermal transport properties and the thermal structure of Mount St. Helens eruptive units. In: Ryan M (ed) Magma transport and storage. Wiley, New York

Saepuloh A, Koike K (2010) Detailed mapping of pyroclastic flow deposits by SAR data processing for an active volcano in the torrid zone. Int J Appl Sci Eng Technol 6:21-25

Schmincke H-U, Swanson DA (1967) Laminar viscous flowage structures in ash-flow tuffs from Gran Canaria, Canary Islands. Geology 75:641-664

Schumacher R, Mues-Schumacher U (1997) The pre-ignimbrite (phreato) plinian and phreatomagmatic phases of the AkdagZelve ignimbrite eruption in Central Anatolia, Turkey. J Volcanol Geotherm Res Elsevier 78:139-153

Sheridan M (1970) Fumarolic mounds and ridges of the Bishop Tuff, California. Geol Soc Am Bull 81:851-868

Sheridan MF, Wang Y (2005) Cooling and welding history of the Bishop Tuff in Adobe Valley and Chidago Canyon, California. J Volcanol Geotherm Res 142:119-144

Smith RL (1960) Ash flows. Geol Soc Am Bull 71:796-842

Sparks RSJ, Gardeweg MC, Calder ES, Matthews SJ (1997) Erosion by pyroclastic flows on Lascar Volcano, Chile. Bull Volc 58:557-565

Sparks R, Tait S, Yanev Y (1999) Dense welding caused by volatile resorption. J Geol Soc Lond 156:217

Sumner J, Branney MJ (2002) The emplacement history of a remarkable heterogeneous, chemically zoned, rheomorphic and locally lava-like ignimbrite: "TL" on Gran Canaria. J Volcanol Geotherm Res 115:109-138

Torres RC, Self S, Martinez M (1996) Secondary pyroclastic flows from the 15 June 1991 ignimbrite of Mount Pinatubo. In: Newhall CG, Punongbayan RS (eds) Fire and mud: eruptions and lahars of Mount Pinatubo, Philippines. Philippines Philippine Institute of Volcanology and Seismology, Quezon City, pp 665-678

Wadge G, Mattioli S, Herd A (2006) Ground deformation at Soufrière Hills Volcano, Montserrat during 1998-2000 measured by radar interferometry and GPS. J Volcanol Geotherm Res 152:157-173

Wallace PJ, Dufek J, Anderson AT, Zhang Y (2003) Cooling rates of Plinian-fall and pyroclastic-flow deposits in the Bishop Tuff: inferences from water speciation in quartz-hosted glass inclusions. Bull Volcanol 65:105-123

Weast R (1974) Handbook of chemistry and physics, 55th edn. CRC, Cleveland, pp F-109-F-112

White HE, Walton SF (1937) Particle packing and particle shape. J Am Ceram Soc 20:155-166

Williams H (1942) The geology of Crater Lake National Park, Oregon, with a reconnaissance of the Cascade Range southward to Mount Shasta. Carnegie Institution of Washington, Olympia, p 162 
Wilson L, Head JW (1981) Morphology and rheology of pyroclastic flows and their deposits, and guidelines for future observations. In: Lipman PW, Mullineaux DR (eds) The 1980 eruptions of Mount St. Helens, Washington. US Geological Survey, Washington, DC, pp 513-524

Wilson C, Hildreth W (2003) Assembling an ignimbrite: mechanical and thermal building blocks in the Bishop Tuff, California. Geology 111:653-670
Wolff J, Wright J (1981) Rheomorphism of welded tuffs. J Volcanol Geotherm Res 10:13-34

Wooster MJ (2001) Long-term infrared surveillance of Lascar Volcano: contrasting activity cycles and cooling pyroclastics. Geophys Res Lett 28:847-850

Zies E (1924) The fumarolic incrustations in the Valley of Ten Thousand Smokes. Contrib Tech Pap Natl Geogr Soc, Katmai Ser. 1, no. 3, pp 159-179 